
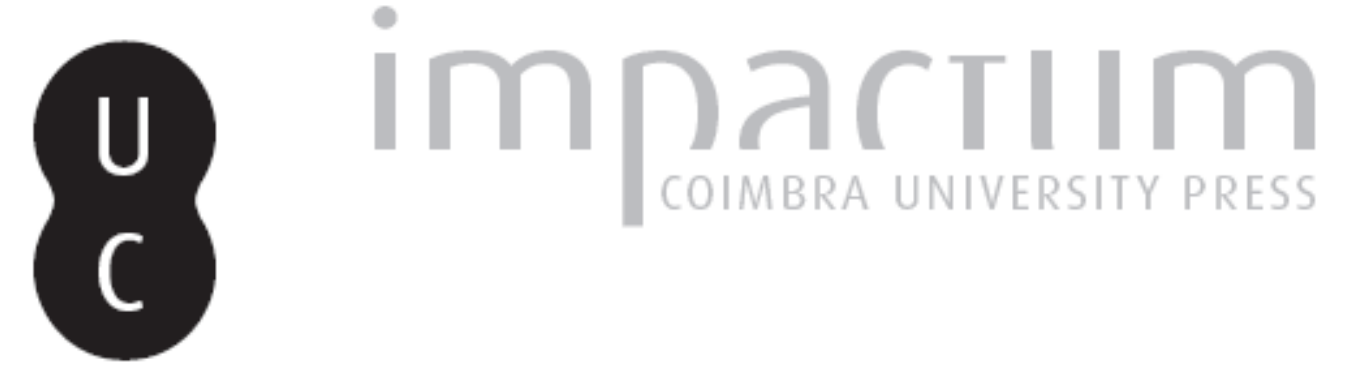

\title{
Teodorico de Freiberg: tratado sobre e a origem das coisas categoriais
}

Autor(es): $\quad$ Augusto, Luís M., trad.

$\begin{array}{ll}\text { Publicado por: } & \text { Faculdade de Letras da Universidade de Coimbra, Instituto de Estudos } \\ \text { Filosóficos }\end{array}$

URL

persistente:

URI:http://hdl.handle.net/10316.2/29453

DOI:

DOI:http://dx.doi.org/10.14195/0872-0851_42_10

Accessed : $\quad$ 26-Apr-2023 09:21:40

A navegação consulta e descarregamento dos títulos inseridos nas Bibliotecas Digitais UC Digitalis, UC Pombalina e UC Impactum, pressupõem a aceitação plena e sem reservas dos Termos e Condições de Uso destas Bibliotecas Digitais, disponíveis em https://digitalis.uc.pt/pt-pt/termos.

Conforme exposto nos referidos Termos e Condições de Uso, o descarregamento de títulos de acesso restrito requer uma licença válida de autorização devendo o utilizador aceder ao(s) documento(s) a partir de um endereço de IP da instituição detentora da supramencionada licença.

Ao utilizador é apenas permitido o descarregamento para uso pessoal, pelo que o emprego do(s) título(s) descarregado(s) para outro fim, designadamente comercial, carece de autorização do respetivo autor ou editor da obra.

Na medida em que todas as obras da UC Digitalis se encontram protegidas pelo Código do Direito de Autor e Direitos Conexos e demais legislação aplicável, toda a cópia, parcial ou total, deste documento, nos casos em que é legalmente admitida, deverá conter ou fazer-se acompanhar por este aviso.

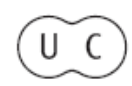




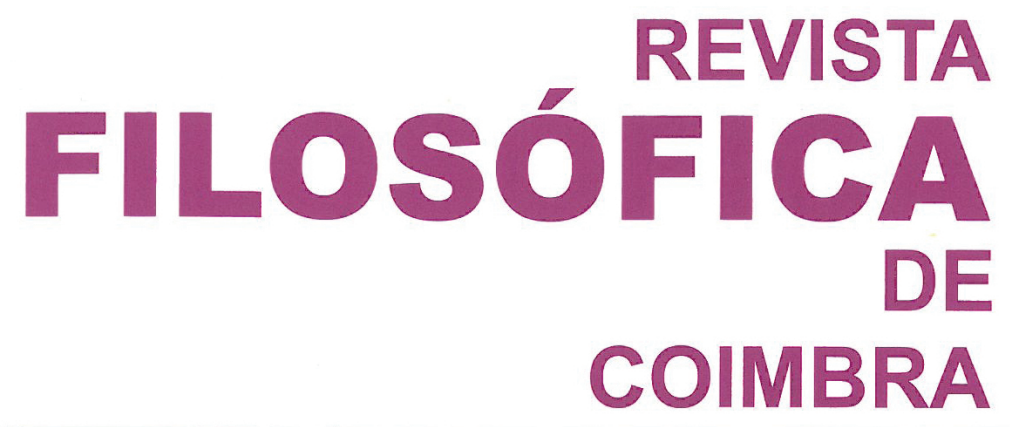

vol. 21 - número 42 - outubro 2012

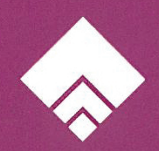




\section{TEODORICO DE FREIBERG TRATADO SOBRE A ORIGEM DAS COISAS CATEGORIAIS}

LUÍS M. AUGUSTO*

\section{Introdução ${ }^{1}$}

\section{Introdução Analítica às Diferentes Partes do Tratado}

\subsection{Capítulo 5}

Após as longas digressões metafísicas dos Capítulos 3 e 4, nas quais Teodorico abordou questões "delicadas" como a unidade da forma substancial e a ordem e classificação das formas na passagem da potência ao acto, este quinto capítulo retoma a questão da origem das coisas categoriais, ou, num vocabulário mais ortodoxo, das categorias dos entes. De facto, os Capítulos 3 e 4 aparecem como uma espécie de "excrescências ontológicas" no De origine: omitidas estas questões metafísicas, os capítulos 1,2 e 5 formariam decerto um todo completo na medida em que neles se desenvolve exactamente aquilo que Teodorico se propusera tratar, a lembrar, a origem das coisas categoriais e como alguns entes (as categorias, nomeadamente os "acidentes") são causados pelo intelecto sem contudo serem coisas de intenção segunda, ou meras coisas de razão, ou ainda como alguns entes de intenção primeira são de facto constituídos pelo intelecto. Por outro lado, os Capítulos 3 e 4 oferecem ao tratado um refinamento metafísico que não só o enriquece deste ponto de vista, como ainda o torna relevante para a problemática metafísica da transição do séc. XIII para o séc. XIV: circunscrito aos Capítulos 1, 2 e 5, o De origine teria provavelmente aparecido na cena filosófica da época em que foi redigido como um texto incompreensível. Pelo contrário, ele teria possivelmente constituído um tratado "aceitável" se inserido na discussão

* Instituto de Filosofia, Universidade do Porto.

${ }^{1}$ Publica-se agora a tradução do Capítulo 5 do texto da autoria de Teodorico de Freiberg Tratado sobre a Origem das Coisas Categoriais, concluindo-se assim a sua publicação integral em três números sucessivos da Revista Filosófica de Coimbra. 
moderna em torno do idealismo, impactando quiçá de modo substancial nesta perspectiva filosófica.

Teodorico começa este capítulo indicando que se vai agora "examinar aquilo que acima se postulou e que de certo modo se mostrou, a saber, que alguns entes que são entes de intenção primeira classificáveis num género são constituídos pelo intelecto" $(\mathbf{5}, \mathbf{1})$ : postulou-se com efeito que na medida em que só há dois princípios para a totalidade dos entes, a natureza ou o intelecto, se o princípio de um ente não é a natureza, então tem de ser o intelecto, e mostrou-se que as categorias são entes de intenção primeira, ainda que entia rationis. Ou seja, Teodorico rejeita que as coisas categoriais, ou as categorias, enquanto coisas de razão - que de facto também são num sentido restrito - sejam necessariamente coisas de intenção segunda. Por exemplo, as diversas intenções formais existentes numa forma substancial única constituem um ente de facto, uma coisa de intenção primeira, como se acabou de ver no Capítulo 4; o mesmo se pode dizer da última forma e da definição. Assim, as categorias surgem como entes de intenção primeira em pé de igualdade ontológica com os entes naturais, de facto existentes na natureza.

Uma das muitas dificuldades apresentadas por este texto que temos em mãos é precisamente a problemática de exactamente que entes de intenção segunda não são meros entes de razão: Teodorico fala de aliqua entia, alguns entes, e para além das coisas categoriais aponta ainda os números (cf. 5, 2), mas a verdade é que a argumentação por ele levada a cabo parece querer concluir que todos os entes de razão são entes de intenção primeira. Tomemos o género e a espécie, por exemplo: a distinção de género e espécie é uma classificação do intelecto, o modo como este classifica os entes naturais, mas é pelo intelecto que um cavalo é um cavalo e não um homem (espécie) e ambos são animais e não, por exemplo, pedras (género). O género e a espécie são por excelência exemplos dos entes dos entes, entia entium, dos quais Teodorico afirma repetidamente que são entes de facto.

Teodorico apela de novo para a autoridade dos "peripatéticos" (estes peripatéticos com aspas são mais propriamente neoplatónicos), segundo os quais os números e a categoria do tempo não são coisas naturais (cf. $\mathbf{5}, \mathbf{2})$, pelo que serão entes criados pelo intelecto. As autoridades latinas são de peso, como convém, sobretudo se o intuito é o de defender teses de Aristóteles e do seu comentador Averróis: Agostinho de Hipona, Boécio, e o Livro dos Seis Princípios, de autor anónimo. Ora, se estas autoridades parecem confirmar a tese de Teodorico, há quem porém tenha argumentos contra ela. Teodorico avança com a apresentação de quatro argumentos contrários à sua tese $($ cf. $\mathbf{5 , 5 - 8})$ e contra os quais toda a argumentação deste Capítulo 5 se dirigirá:

$1^{\circ}$ argumento: $O$ intelecto é uma faculdade passiva segundo Aristóteles.

$2^{\circ}$ argumento: Todas as coisas que são pelo intelecto parecem ser coisas de razão ou coisas de intenção segunda.

$3^{\circ}$ argumento: Pela operação do intelecto nada se "põe" com relação a uma coisa para além daquilo que é pensado, intellectum, mas a entidade dos intellecta, entes de pensamento ou conceitos, consiste na sua mera apreensão. $4^{\circ}$ argumento: Não há uma verdadeira diferença entre o intelecto e a imagi- 
nação em termos de apreensão de uma coisa; ora, sabemos que as coisas não são como as pinta a imaginação.

Para Teodorico, trata-se de não ver que as causas são de dois tipos diferentes, sendo necessário estabelecer uma distinção entre causas em termos da potência (causae secundum rationem potentiae) e causas em termos do acto (causae secundum rationem actus): no primeiro caso temos a matéria ou algo possuindo a noção e o modo da matéria (a causa material), enquanto no segundo estamos face ao fim, à forma e ao eficiente (ou seja, às causas final, formal e eficiente). A grande diferença é que em termos da potência a causalidade é por movimento e transmutação (per motum et transmutationem), podendo-se falar de geração e de acção de criar (factio) na medida em que o movimento e a transmutação ocorrem num sujeito, quer a partir da sua própria noção (geração essencial), quer a partir de uma forma e de uma determinação (dispositio) que se encontrem num sujeito (geração acidental); quanto à causalidade em termos do acto, esta é (1) por suposição ${ }^{2}$ e por intenção com respeito ao fim (ex suppositione <finis $>$ et per intentionem <finis $>$ ), (2) por informação (per informationem) no que respeita à forma, e (3) de modo produtivo (executive) em relação ao eficiente. Teodorico explica em detalhe em que consiste a diferença entre todas estas causas $\mathbf{( 5 , 1 0 -}$ 15; ver Quadro 4 para um sumário) e propõe-se em seguida "ver se o intelecto tem o carácter de uma causa com respeito a alguns entes, e se tal for o caso, de acordo com que tipo de causa" $(\mathbf{5}, \mathbf{1 6})$.

Teodorico começa por estabelecer que um ente cuja entidade é em si mesma (um ente por essência) e de modo simples (excluindo-se, pois, os entes por acidente e os entes concretos, entia ut nunc) relaciona-se com outro ente por si mesmo e de acordo com a sua própria natureza (vs. por comparação) de dois modos possíveis: ou é igual a esse outro ente, ou é a sua causa, ou seja, ou se dá o caso que há entre eles uma identidade, ou se verifica que entre eles há uma relação de causalidade (causa e efeito). Estes são os modos que reflectem uma dependência real entre dois entes; se eliminarmos estes modos, as naturezas e determinações das coisas são absolutas (vs. relativas) e independentes umas das outras (cf. 5, 17). Ora, acontece que a entidade do intelecto humano, pois que é um dos entes mais formais da natureza, é em si mesma; de facto, embora em termos naturais ele se encontre em cada indivíduo separadamente, esta presença não implica a multiplicidade, mas sim uma "unidade formal" (sem, contudo, implicar que se trata de um só e o mesmo intelecto para toda a espécie humana, tese dita averroísta que Teodorico não partilha; cf. 5, 18-19). A relação que existe entre o objecto e as faculdades activas do intelecto (nomeadamente do intelecto agente) é uma relação essencial, e isto de um modo mais evidente, pois faz parte da essência do intelecto ter uma tal relação com os seus objectos, os inteligíveis, intelligibilia. Mas visto que o intelecto não é idêntico aos seus objectos, resta pois que a relação que ele tem com eles é-o de causalidade, uma relação na qual

2 Ou seja, na suposição que um fim deve ser alcançado. 
Quadro 4

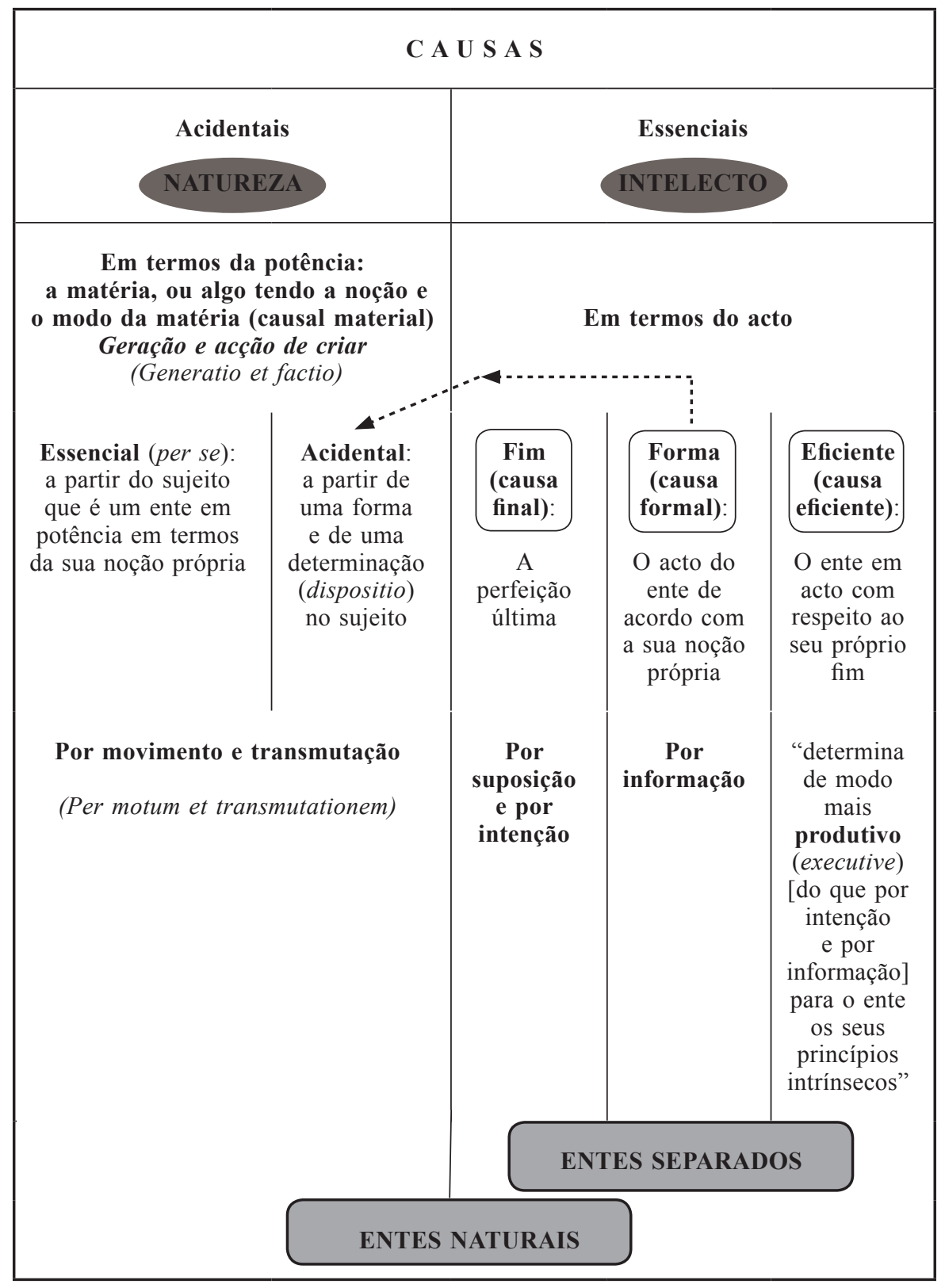

A Causalidade segundo Teodorico de Freiberg (De or., 5, 9-26). 
o intelecto assume a função da causa graças ao seu carácter incomparavelmente mais formal do que qualquer dos seus objectos ${ }^{3}$.

As causas em termos do acto, as causas essenciais dos entes, as quais têm "de antemão em si mesmas o seu causado graças a uma faculdade mais formal do que o é o próprio causado, caso contrário não teriam em relação aos entes o carácter de causa" - uma tese neoplatónica com raiz no Estagirita (cf. De an. III, 5, 430a18-19) -, são pois do domínio do intelecto (cf. 5, 20-1). No caso da relação entre os órgãos dos sentidos e os objectos sensíveis, os sensibilia, estes são com efeito a causa da actualização daqueles, e isto devido ao modo de apreensão em causa, o qual envolve a matéria ou algo possuindo a noção e a natureza da matéria, pelo que estamos face às causas em termos da potência (cf. 5, 24-5; cf. Quadro 4). É certo que mesmo a apreensão dos objectos dos sentidos não dispensa a presença de uma forma (cf. Quadro 4), mas neste caso trata-se de formas que se formam nos órgãos dos sentidos de acordo com o movimento causado pelos objectos sensíveis nesses órgãos, pelo que é correcto atribuir às coisas sensíveis o carácter de causas ${ }^{4}$.

Quando, porém, estamos no domínio dos entes simples, ou seja, das formas puras (sem matéria), então estamos face a princípios de conhecimento (principia cognitionis) que são a causa dos objectos na medida em que esses princípios determinam em relação a um objecto a noção pela qual ele é apreensível. Visto que a causa desses princípios é o intelecto, o qual determina assim em relação a si próprio o seu próprio objecto, o intelecto é a causa desses objectos (cf. $\mathbf{5}$, 26). Na explicação deste segundo modo de apreensão, a apreensão inteligível, Teodorico vai alicerçar as seguintes teses fundamentais do seu tratado:

1. “Os objectos não têm o carácter de uma causa com respeito ao intelecto em acto

1.1. tanto porque o movimento do objecto não chega até ele - pois que ele nem é um corpo nem uma faculdade no corpo, mas sim algo separado de acordo com o Filósofo,

3 Note-se que aqui a causalidade implica necessariamente a não-identidade, pois que nada de formal se encontra simultaneamente na causa e no seu efeito se a causa é verdadeiramente causa, uma tese neoplatónica atribuída ao Pseudo-Dionísio (De div. nom. II, 8, 645C-D) e que será fundacional no pensamento dos membros da "Escola de Colónia" (cf. por exemplo a Quaestio parisiensis I de Eckhart, nomeadamente n. 9-11 em Die deutschen und lateinischen Werke. Vol. V: Die lateinischen Werke (LW V): Quaestiones Parisienses una cum quaestione Magistri Consalvi. Org. e trad. de B. Geyer. Estugarda: W. Kohlhammer, 1936ss, pp. 45-6).

${ }_{4}$ Como Teodorico diz em 5, 25, "Tudo aquilo que é causa do sujeito - seja em fazendo $<-0>$ seja em determinando $<-0>$, graças ao qual o sujeito se encontre na determinação final que é a necessidade de receber uma forma que tem de ser produzida e existir no sujeito - é causa da forma na medida em que é a causa da união graças à existência da qual antes de mais a forma tem existência. E neste modo é evidente por que razão as faculdades são mais formais do que os seus objectos, embora os objectos com respeito a elas tenham o carácter de causa, como se disse." [sublinhado nosso] 
1.2. como porque no acto de conhecimento não se pressupõe o objecto de acordo com a sua noção de objecto, graças à qual ele possa mover o intelecto e assim ter o carácter de uma causa,

2. mas, pelo contrário, no acto de conhecimento o objecto começa a ter a noção própria de objecto.

2.1. O objecto do intelecto é a quididade, de acordo com o Filósofo, ou a coisa em termos da sua quididade;

2.2. porém, o intelecto de modo nenhum apreende esta quididade a não ser distinguindo e determinando os próprios princípios da coisa, os quais o Filósofo chama as partes da forma que a definição significa.

3. Só isto é conhecer (intelligere), ou seja, apreender uma coisa de acordo com a determinação desses princípios dela;

3.1. de outro modo o intelecto não seria diferente da faculdade cogitati$v a$, a qual pode despir a intenção de uma substância de modo a que, despida na mesma $<$ faculdade $>$, ela se mantenha despida de todas as imagens, como diz Averróis, e de todos os apêndices acidentais.

3.2. E tal é a intenção da substância nessa determinação que de acordo com ela uma forma é produzida pela faculdade do intelecto agente no intelecto possível, graças à qual < faculdade> os seus princípios são determinados em relação à própria forma ou a uma coisa segundo a sua forma. E a partir disto a forma tem já a noção de quididade e a própria coisa tem uma existência quiditativa. E esta é a noção própria do objecto da faculdade intelectiva." [sublinhados nossos]

Ao afirmar, em 5, 27, que "o ente pelos seus princípios não é causa de coisa nenhuma" no que diz respeito à cognição, Teodorico está a rejeitar de forma clara o mote da filosofia medieval, veritas est adaequatio rei et intellectus, que definia a noção epistemológico-metafísica de verdade como a adequação da coisa (ou seja, do objecto do conhecimento) e do intelecto; contra este mote, adopta a versão albertiniana que fazia desta adequação uma relação unívoca na qual a coisa conhecida depende do intelecto, veritas est adaequatio rei ad intellectum (Alberto Magno, Liber de praedicamentis II; ed. Borgnet, p. 193). Tratar-se-á aqui possivelmente de uma passagem de uma epistemologia centrada no objecto criado ou a criar, no mundo real e/ou no Verbo, para uma epistemologia centrada no intelecto enquanto causa do seu próprio objecto. Seja como for, se o objecto do conhecimento é nada mais nada menos que o mundo real, então o intelecto é visto como a causa da própria realidade. É esta a tese que Teodorico agora irá defender de forma mais ou menos directa, começando precisamente por estabelecer que é pelos princípios do próprio intelecto - e não pelos princípios do próprio ente - que o ente é constituído como objecto de conhecimento ${ }^{5}$. Em

5 Estamos, é claro, no seio do idealismo. Mais precisamente, de um idealismo epistemológico e que de certo modo "antecipa" o idealismo transcendental kantiano, falando explicitamente de constituição do objecto de conhecimento. De facto, numa obra posterior ao tratado que temos em mãos, De intellectu et intelligibili, Teodorico apresentará uma 
5, 28, Teodorico explica esta causalidade com origem no próprio intelecto, mais especificamente nos seus princípios, para logo de seguida afirmar a tese que o modo de conhecer (modus intelligendi) é dador da própria quididade e existência de um ente (cf. 5, 30), tese conforme à sua metafísica cunhada pela identidade entre existência e essência ${ }^{6}$.

Em 5, 31-4, a argumentação de Teodorico assume um carácter refinado:

(1) Um homem é um ente natural.

(2) Um homem é também a sua noção, ou seja, animal racional.

(3) $\mathrm{Na}$ noção de homem encontramos duas distinções:

(3.1) A distinção entre animal e racional;

(3.2) A distinção entre esta noção formal e o ente natural que é o homem.

(4) Estas distinções não são o produto de uma operação da natureza, pois esta termina numa coisa natural enquanto tal.

(5) Se não são produto da natureza, têm necessariamente de sê-lo do intelecto.

(6) $\mathrm{O}$ intelecto, ao distinguir, faz ou produz de facto (efficit).

(7) Visto que a noção de um ente é a mesma coisa que o próprio ente, ou seja, a essência é a mesma coisa que a existência, o intelecto faz de facto os entes.

(8) A operação do intelecto é a operação de conhecer ou pensar.

(9) Logo, o intelecto faz de facto os entes ao conhecê-los ou pensá-los.

(10) O objecto do intelecto é necessariamente simples e em acto: o universal.

(11) Pois que o objecto do intelecto é o universal, então ele é em acto.

(12) O intelecto constitui de facto - ou seja, em acto - o ente que é o seu objecto.

(11) Este fazer (factio) pela universalidade é análogo ao modo de criar da natureza (ver Quadro 5 para esta analogia).

Chegado aqui $(\mathbf{3}, \mathbf{3 4})$, Teodorico crê ter mostrado que as coisas de intenção segunda, entes de razão ou formas da parte do intelecto pelas quais as coisas são conhecidas, são, por analogia com a natureza (ver Quadro 5), constitutivas dos entes. $\mathrm{O}$ autor vai apoiar (em 3, 35) esta conclusão na autoridade de Aristóteles, Agostinho e Anselmo, e vai fazê-lo pela via daquilo que hoje chamaríamos uma filosofia da linguagem: a palavra (o verbo, ou o substantivo, ainda) que exprime a definição, quer como imagem acústica quer como simples conceito ou ainda representação, é dadora (constitutiva) de existência. Sabemos já que estas "palavras" são coisas de intenção segunda, conceitos de conceitos ou categorias gramaticais.

lista de doze princípios que evoca de forma surpreendente as tábuas kantianas dos juízos e das categorias (ver nota de rodapé a 5, 27)

${ }^{6}$ Ex.: non possum intelligere essentiam hominis, nisi intelligam esse actualis eius. (De ente et essentia II, 1, 4) 
Quadro 5

\begin{tabular}{|c|c|}
\hline \multicolumn{2}{|c|}{ CRIAÇÃO (FACTIO) } \\
\hline Na Natureza & No Intelecto \\
\hline $\begin{array}{l}\text { Uma coisa é pelo seu acto formal em } \\
\text { si mesma princípio de uma operação } \\
\text { causal que }\end{array}$ & $\begin{array}{l}\text { Uma forma em acto é princípio de uma } \\
\text { operação inteligível que }\end{array}$ \\
\hline 1) constitui um ente natural; & $\begin{array}{l}\text { 1) constitui um ente em termos da sua } \\
\text { quididade, ou seja, numa existência qui- } \\
\text { ditativa; }\end{array}$ \\
\hline $\begin{array}{l}\text { 2) cria os princípios intrínsecos de um } \\
\text { ente graças à qual criação algo é cons- } \\
\text { tituído. }\end{array}$ & $\begin{array}{l}\text { 2) cria os princípios deste ente em ter- } \\
\text { mos da sua quididade como aqueles } \\
\text { graças aos quais algo é. }\end{array}$ \\
\hline $\begin{array}{l}\text { Em algumas coisas causais encontram-se } \\
\text { certas determinações naturais e formas } \\
\text { acidentais graças às quais se determina } \\
\text { a causalidade da natureza entre a causa } \\
\text { e o causado (a quantidade, o movimento } \\
\text { local, a luz, etc.). }\end{array}$ & $\begin{array}{l}\text { No intelecto existem certas formas que } \\
\text { determinam uma operação inteligível: as } \\
\text { coisas de razão que são coisas de inten- } \\
\text { ção segunda. }\end{array}$ \\
\hline
\end{tabular}

Analogia entre os Modos de Criar da Natureza e do Intelecto segundo De or., 3, 34.

Teodorico liga assim a sua tese do intelecto como princípio causal à linguagem: o objecto do intelecto é simples, puramente formal; ora, nada é mais formal do que a noção que define uma substância; o substantivo que significa uma substância é precisamente a sua definição (por exemplo, o substantivo homem significa a essência do homem ao remeter para a sua definição como "animal racional mortal"). Por outro lado, segundo Teodorico é pela noção ou definição que um ente tem uma existência quiditativa, essencial, ou seja, real. Viu-se acima $(5,32)$ que a noção é fruto da operação do intelecto; a conclusão que o filósofo de Freiberg parece querer tirar é que o próprio homem é um fruto da operação intelectual e que o é via a linguagem, uma produção da lavra do intelecto. É importante chamar a atenção do leitor para o facto que Teodorico recorre aqui a autoridades infrequentes neste texto, Agostinho de Hipona e Anselmo; com efeito, lembramos que as grandes autoridades nas quais este tratado se apoia são Aristóteles e o seu Comentador, Averróis, corroborando assim o objectivo de Teodorico de expor a problemática deste texto a partir do ponto de vista de Aristóteles e dos peripatéticos. Que no contexto de uma análise do papel da linguagem na causalidade do intelecto o autor se vire para filósofos latinos, tal pode dever-se simplesmente ao facto que nestes uma teoria metafísica da linguagem se mostrará talvez mais desenvolvida que naqueles.

Em 3, 36, Teodorico explica a simultaneidade das causas que faz com que um ente produzido pelo intelecto possa de igual modo ser um ente natural, ou seja, simultaneamente ente de razão e ente natural. Um ente pode ter diversas causas, 
não deixando por isso de ser um e o mesmo ente; nomeadamente na medida em que a causa primeira está envolvida na sua criação, ele é um ente, e na medida em que é produzido por uma causa natural, ele é um ente natural, sem porém deixar de ser um e o mesmo ente na realidade (re), embora a razão (ratione, pela ou na razão) o reduza às suas diferentes causas. Além disso, nenhuma destas causas é supérflua, sendo de igual modo necessárias para que um ente seja o ente que é. Podemos facilmente antecipar qual o objectivo de Teodorico com esta argumentação: além de uma operação natural, um ente pode ser causado por uma operação intelectual, sem que por isso esta última causa seja supérflua.

A argumentação é desenvolvida em $\mathbf{5 , 3 7}$. Teodorico concilia as três causas de um ente natural: a causa primeira, que lhe dá uma existência de modo simples ou formal ao determinar-lhe os princípios de ser (principia essendi) quanto à sua (dos princípios) essência, ou seja, ao fazer com que ela seja diferente do nada; a causa natural, a qual lhe determina os princípios em termos da potência e do acto numa existência natural; e a causa intelectual, pela qual ela tem uma existência quiditativa na medida em que lhe são determinados os princípios que são partes da forma que é a quididade que a definição significa. Estamos aqui perante os três modos de principiar ou originar um ente introduzidos logo no início do primeiro capítulo deste tratado. Assim sendo, e como se verá, um ente natural interessa como objecto de estudo simultaneamente, embora por razões diferentes, ao lógico, ao físico e ao metafísico. Põe-se de imediato a pergunta: e o teólogo? Lembramos que Teodorico começara por afirmar que ia abordar a questão de um ponto de vista puramente filosófico; embora tal possa não parecer revolucionário em si (é-o, de facto), o interessante é verificar o modo como ele se mantém fiel a este objectivo. Note-se porém a brevíssima "manutenção" da causa divina em 5, 36.

Lembramos que Teodorico está a fazer este longo e intrincado percurso para argumentar contra os quatro obstáculos que se podem pôr à tese segundo a qual os entes produzidos pelo intelecto são entes reais (ver acima). Resumido pelo próprio autor, uma coisa de razão ou de intenção segunda "não tem uma existência quiditativa senão enquanto existe no intelecto e enquanto é inteligível, e não tem esta existência em si mesma fora do intelecto, ao que parece: a existência quiditativa não parece ser possível senão no intelecto pelo facto que uma coisa não tem este modo a não ser quando os seus próprios princípios lhe são determinados como tais pelo intelecto" $(\mathbf{5}, \mathbf{3 9})$.

A argumentação que se avizinha continuará a ser longa e intrincada, e continuaremos a sistematizar cada passo de importância. Assim, em 5, 40, Teodorico vai estabelecer uma analogia entre a relação que os sentidos têm com o sensível e a relação do intelecto com os inteligíveis. Sistematizando: o sensível enquanto sensível diz-se de três modos de acordo com a faculdade de duplicação (vis reduplicationis) que é característica da sensação (por exemplo, a visão é a duplicação ou criação de imagens das coisas materiais): diz-se de algo que é sensível enquanto sensível 1) quando existe num órgão dos sentidos como a intenção, a forma ou a semelhança - ou seja, a duplicação - de uma coisa ou fenómeno exterior; 2) enquanto nele termina a operação de um órgão dos sentidos, ou seja, é percebido ou percepcionado, e 3) enquanto é a causa da apreensão por um órgão dos sentidos. Como se verá no parágrafo seguinte, nestes dois últimos modos o sensível 
enquanto sensível é objecto da sensação. O mesmo se pode dizer (em $\mathbf{5 , 4 2}$ ) do inteligível enquanto inteligível: 1) de um modo, designa a intenção de uma coisa ou a forma no intelecto por meio da qual a coisa é conhecida; 2) de outro modo, o inteligível diz-se enquanto é apreendido pela operação inteligível; 3) de um terceiro modo, o inteligível diz-se enquanto tal na medida em que é a causa da apreensão pelo intelecto (ou seja, na medida em que nele se encontra a noção pela qual pode ser conhecido, e isto é enquanto tem uma existência quiditativa). No modo 1) o inteligível não se encontra fora do intelecto nem tem o carácter de objecto; nos modos 2) e 3) ele encontra-se fora do intelecto e tem o carácter de objecto. Ora, como nestes dois últimos modos o inteligível tem uma existência quiditativa, e esta é da lavra do intelecto, por uma determinação do objecto a partir dos seus próprios princípios, o inteligível, enquanto objecto do intelecto, é produzido por ele (cf. 5, 43). Obviamente, o intelecto não é uma causa material, mas também não é nem uma causa formal, nem uma causa exemplar, nem sequer ainda final (cf. 5, 44 para a argumentação acessível que Teodorico sucintamente elabora).

Parece pois que o intelecto é, com respeito ao seu objecto, uma causa eficiente, mas as coisas não são assim tão simples: porque o eficiente só age em vista de um fim, o intelecto é também uma causa final. Mas, porque se fala aqui do intelecto especulativo, ou seja, o intelecto que recebe os objectos enquanto imagens ou duplicações, os objectos especulativos, parece que para tal os próprios objectos apresentam eles também uma causa final na medida que uma tal causalidade deverá fazer parte da sua definição. Teodorico refuta esta argumentação: o intelecto não precisa de ter um conhecimento prévio dos seus objectos, agindo em vista de um fim de um modo natural, ou seja, do mesmo modo que alguns entes naturais tendem para os seus fins sem os conhecerem previamente (cf. $\mathbf{5 , 4 5}$ ).

Teodorico vai agora debruçar-se sobre a criação por parte do intelecto:

1) Há decerto entes que não são pelo intelecto aquilo que são: os entes naturais. Mas o intelecto produz neles a entidade, graças à qual eles são algo específico e têm uma existência quiditativa. Ou seja, trata-se de constituir, ainda que de uma forma diferente da natural. Estes são os entes que pertencem a uma substância e são naturalmente concretos (vs. puramente abstractos); fala-se aqui das quantidades, das qualidades, e outras coisas que tais (cf. acima 2, 18-33; cf. 5, 47).

2) Em seguida, em relação aos entes naturais o intelecto produz entes que são como que modos deles, à maneira de medida, relações, ou circunstâncias; estes entes são de um modo completivo (ou seja, que completa) por parte do intelecto (cf. acima 2, 34-54; cf. 5, 48).

3) Outros entes há ainda que em relação aos entes naturais têm o carácter de propriedades e paixões essenciais; estes entes são de dois modos, conforme se considere a sua noção definitiva a partir dos seus princípios intrínsecos enquanto são entes de um modo absoluto (cf. acima $\mathbf{2 , 4 4}$ ) ou se considere na sua noção definitiva as causas naturais, a saber, as causas eficiente e final (cf. 2, 45): os primeiros tomam a sua entidade a partir de uma operação do intelecto, enquanto os segundos são entes naturais e propriedades de entes naturais (cf. $\mathbf{5 , 4 8}$ ). 
4) Teodorico resume assim a penosa argumentação do segundo capítulo que divide - provisoriamente - as categorias aristotélicas em entes naturais e entes produzidos pelo intelecto. Mas vai agora introduzir um novo tipo de entes de uma operação natural, nem substâncias nem determinações ou acidentes de substâncias, pelo que o acto de pensá-los abstrai de todo o ente natural e de todos os princípios naturais: os entes matemáticos. Enquanto abstractos, eles são anteriores à natureza. Mas há mais do que uma natureza, segundo Teodorico: às naturezas física e metafísica há ainda que juntar a natureza matemática, cujo aspecto distintivo é a sua dependência absoluta do intelecto. Teodorico mostra esta antecedência através do exemplo de uma demonstração da geometria (cf. 5, 51): pela natureza ou de acordo com a existência natural o círculo é anterior às linhas rectas, mas as demonstrações absolutas destas são anteriores às demonstrações do círculo. Esta dependência absoluta do intelecto faz com que estes entes não pertençam a nenhum género, a menos que sejam incluídos no género da quantidade por uma consideração meramente lógica.

Em 5, 52, Teodorico vai terminar esta longa argumentação com a já esperada conclusão: todos estes entes são entes de intenção primeira. Quanto aos entes de intenção segunda, estes não existem fora do intelecto, ao contrário dos entes de intenção primeira, sendo apenas formas do intelecto por meio das quais as coisas se tornam racionais; eles são considerados pelo intelecto apenas por acidente, na medida em que ele considera os entes de intenção primeira por si mesmos, e tomam a sua entidade e a sua quididade por acidente. Neste processo, eles de certo modo tomam o modo de ser dos entes de intenção primeira, mas não se tornam simplesmente em entes de intenção primeira (cf. 5, 53); ao contrário destes, que só são considerados em si e essencialmente, logo nunca como não-entes, os entes de intenção segunda podem ser considerados em relação ao não-ente $(\mathrm{cf} . \mathbf{5 , 5 4})$. Está assim deslindada a diferença entre as coisas de intenção primeira e as coisas de razão ou coisas de intenção segunda, embora sejam ambas constituídas pelo intelecto. Isto responde à $2^{\mathrm{a}}$ objecção acima.

A refutação da $1^{a}$ objecção $($ em $\mathbf{5 , 5 6})$ apresenta-se dupla: em primeiro lugar, se se aceita que as coisas de razão ou entes de intenção segunda são uma criação do intelecto, então não se pode negar o carácter activo deste, nomeadamente no que diz respeito às coisas de intenção primeira na medida em que também elas são fruto de uma operação intelectual; além disso, o intelecto possível só é passivo por comparação com o intelecto agente, pelo qual é actualizado, não o sendo em relação ao seu objecto de conhecimento, o qual é de facto quidificado por ele na operação inteligível ou acto de conhecimento.

No que diz respeito à $3^{\mathrm{a}}$ objecção, a refutação passa pela causalidade múltipla: um ente pode ser integralmente produzido a partir de causas diferentes, como por exemplo um homem, que é um ente natural existente fora do intelecto graças a uma causalidade natural mas sendo aquilo que é (i.e., uma coisa específica com uma existência quiditativa) a partir dos princípios próprios do seu género, animal e racional, por uma determinação do intelecto. $\mathrm{O}$ mesmo se passa no caso das determinações relativas (relativae habitudines) pertencentes aos entes 
naturais: embora estas pertençam aos entes naturais em virtude da noção do seu fundamento, importado no seu conceito com relação a uma substância, elas são constituídas a partir dos seus próprios princípios, os quais, porém, lhes são determinados pela razão (cf. 5, 57).

Finalmente, a $4^{\mathrm{a}}$ e última objecção, segundo a qual não há uma verdadeira diferença entre o intelecto e a imaginação, pelo que nada é de facto ou na realidade criado pelo intelecto com relação a uma coisa natural, é refutada do seguinte modo: os actos do intelecto e da imaginação são ao mesmo tempo semelhantes e diferentes; são semelhantes na medida em que os seus actos compostos não se concretizam num ente natural (por exemplo, e da lavra de Teodorico: posso imaginar um homem como tendo cornos, mas na realidade ele não os terá); são diferentes na medida em que só o acto do intelecto é informativo, o qual consiste na apreensão das intenções simples ou, o que é o mesmo, de entes não compostos. Ora, dá-se que esta apreensão é segundo a quididade dos entes, produzindo neles "a existência quiditativa a partir dos próprios princípios que são as partes da forma que a definição significa" $(\mathbf{5}, \mathbf{5 8})$; porque um ente só pode ser conhecido ou pensado (intellectum) graças à sua definição, é somente neste acto informativo que o ente adquire a noção de objecto (do conhecimento ou do pensamento). Assim, a diferença entre o intelecto e a imaginação é que esta, tal como a sensação, necessita tanto da espécie do objecto como da noção própria deste pela qual ela o possa apreender, pelo que é um princípio passivo com relação ao objecto, enquanto o intelecto tem o carácter de princípio activo ou causal, dador da forma (i.e., informativo) pela qual o ente adquire a sua noção própria de objecto.

Teodorico crê ter demonstrado a existência de três tipos de entes: os entes de intenção segunda, pura e simplesmente coisas de razão na medida em que são a partir da razão e formas da parte desta pelas quais as coisas são cognoscíveis ou pensáveis; os entes naturais, como a substância e a qualidade (cf. Quadro 3 acima), que são aquilo que são de acordo com a natureza e a partir de um acto natural; e os entes de intenção primeira, entes "como que intermédios" (quasi medio modo; cf. $\mathbf{5}, \mathbf{5 9}$ ), que "quanto àquilo que se significa formal e principalmente pelo termo são a partir de uma operação do intelecto, mas em termos de uma qualquer natureza que eles importam no seu conceito, quer esta natureza seja uma substância, quer algo concreto de uma substância" $(\mathbf{5}, \mathbf{5 9})$.

O que é que tudo isto significa? Teodorico partira da rejeição dos entes criados pelo intelecto como meras res rationis, ou coisas de razão, e propusera-se mostrar que alguns entes produzidos pelo intelecto são mais do que meros entes de razão, sendo de facto entes de intenção primeira (por oposição a entes de intenção segunda). Se se seguir uma concepção comum desta distinção, então o que temos é sempre e exclusivamente coisas de razão no sentido em que só existem no intelecto; segundo esta perspectiva, os entes de intenção primeira são os conceitos das coisas naturais (ex.: homem, cavalo) e os entes de intenção segunda são os conceitos desses conceitos (ex.: substantivo). Teodorico desloca esta questão para a problemática já de si complexa das categorias, começando por conceber três, e apenas três delas, como entes naturais (a lembrar: a substância, a qualidade e a quantidade), vendo as restantes como entes produzidos pelo intelecto, sem 
porém serem por tal entes de intenção segunda. Parece assim haver entes que são criados pelo intelecto mas que não são por tal meros entes de razão. Parece, do mesmo modo, haver entes naturais que existem fora do intelecto, tendo sido criados por uma operação natural e sendo em si mesmo princípios de movimento ou mudança natural. E parece ainda haver entes "intermédios" no sentido em que, embora criados pelo intelecto, têm uma função tal - a informação - que sem eles os entes naturais não são pensáveis ou cognoscíveis: os entes naturais têm a noção - a sua noção própria, com efeito - de objecto do intelecto em virtude de um acto deste. Logo no início do tratado Teodorico afirmara que só há dois tipos de princípios, a natureza (princípios extrínsecos; as causas final e eficiente) e o intelecto (princípios intrínsecos; as causas formal e material); se um deles não é o princípio de um ente, o outro forçosamente sê-lo-á. Porém, o autor do tratado também aceita uma causalidade múltipla - ou, melhor, dupla, visto que só há dois tipos de princípios originários -, permitindo a junção dos princípios naturais e inteligíveis: trata-se daquilo que ele denomina os entes do terceiro modo (cf. 1, 5), algo extrínseco a uma coisa natural mas sendo contudo o princípio a partir do qual esta subsiste formalmente na medida em que adquire a sua quididade ou entidade a partir desse princípio graças à sua própria significação ou conceito que dela fazemos (cf. Capítulo 1, nota 32). Eis as categorias outras que a substância, a qualidade e a quantidade.

É óbvio que os entes do terceiro modo, ou as coisas de intenção primeira, põem em causa, ontologicamente, os entes naturais, pois que estes só adquirem a sua entidade ou quididade a partir destes entes criados por um acto do intelecto; serão eles "menos entes" ou "entes menores"? Por outro lado, serão os entes exclusivamente da lavra do intelecto ontologicamente superiores, "mais entes" ou "entes maiores"? Teodorico termina o tratado de forma a conciliar todas as perspectivas de relevo, a saber, do metafísico, do físico e do matemático: no caso do primeiro, o qual considera o ente somente enquanto ente, mais não lhe interessa do que a forma na ausência de todas as causas naturais; o físico perscruta o ente natural na sua vertente material, mas também pelas causas final e eficiente; o matemático, porque abstrai com respeito às causas final e eficiente, e de igual modo no que respeita à matéria, só considera a forma. É pois evidente que o metafísico e o matemático se distinguem claramente do físico, mas parece não haver qualquer diferença entre ambos. Teodorico deslinda de imediato uma tal possível confusão: a diferença entre o metafísico e o matemático reside (1) no sujeito e (2) no modo de ser do sujeito. Vejamos como:

(1) O objecto de estudo do metafísico é o ente enquanto ente e os entes que pertencem a um ente essencialmente, quer em termos de partes do ente, quer em termos de propriedades do ente. Porém, o objecto do matemático é o ente de um género determinado, o qual não inclui a noção geral do ente como uma parte de si, dependendo essencialmente dos seus próprios princípios, tal como é o caso com os sujeitos das outras ciências diferentes da metafísica.

(2) O metafísico considera os entes que têm um modo de ser natural, ou seja, inerem em termos da quididade e da forma que se encontra de facto na natureza, enquanto o matemático considera os entes de uma perspectiva puramente abstracta, ou seja, num modo se ser intelectual. 
Teodorico termina o tratado pondo a questão - e remetendo para uma obra a ser redigida posteriormente - se é possível agora decidir se conhecemos entes separados ou entes individuais, uma problemática fundamental do pensamento medieval. Mas é certo que este tratado já forneceu elementos para a resposta. Quais, fica como exercício para o leitor.

\section{SOBRE A ORIGEM DAS COISAS CATEGORIAIS DE TEODORICO DE FREIBERG}

\section{Capítulo 5}

(No qual se mostra como o intelecto tem o modo de um princípio causal com respeito a alguns entes enquanto são entes de intenção primeira, os quais são constituídos por uma operação do intelecto de acordo com os peripatéticos) ${ }^{7}$

(1) Temos de examinar aquilo que acima se postulou e de certo modo se mostrou, a saber, que alguns entes que são entes de intenção primeira classificáveis num género são constituídos pelo intelecto. Disse-se com efeito acima por que razão estes entes, quanto àquilo que formal e principalmente se significa pelo termo, não podem ser a partir de um acto da natureza ${ }^{8}$. Visto que não há outro princípio no universo dos entes senão a natureza ou o intelecto, se não é a natureza, então é necessário que o intelecto seja o princípio causal desses entes.

(2) Confirma-se a tese <por nós> proposta por aquilo que se encontra nos filósofos acerca da causalidade de certos entes que segundo eles são constituídos por um acto do intelecto. Parece com efeito ter sido essa a tese do Filósofo ${ }^{9} \mathrm{e} o$ seu Comentador claramente expõe isto acerca do tempo no livro IV de Acerca da Física ${ }^{10}$. Agostinho estabelece isto de modo claro e numa extensa dissertação no livro XI das Confissões ${ }^{11}$. Boécio diz no livro $A$ Trindade ${ }^{12}$ acerca do número que este não é uma coisa natural. E se o tempo é tal ${ }^{13}$ na opinião dos filósofos, que

7 Teodorico vai agora defender a tese principal deste tratado, a lembrar, que alguns entes de intenção primeira são constituídos pelo intelecto. De realce é o facto de ele afirmar apoiar-se nos peripatéticos como autoridade para defender uma tese que é acima de tudo idealista, com raízes tanto platónicas como aristotélicas, mas transmitidas e desenvolvidas pelos neoplatónicos e recebidas pelos filósofos árabes como sendo aristotélicas na essência.

8 Lembra-se a conclusão de Teodorico em 2, 14: os entes que são produzidos a partir da noção formal são criados pelo intelecto, visto que a natureza não distingue entre a coisa-sujeito e a noção da coisa-sujeito.

9 Aristóteles, Phys. IV, 11, 218b27-219a1, 219a23-9; ibid., IV, 14, 223a21-9.

10 Averróis, In Aristotelis Phys. IV, comm. 97, Venetiis 1562, 178rB; ibid., IV, comm. 100, 180vG-I; ibid., comm. 131, 202rB-vH.

11 Agostinho de Hipona, Conf. XI, 14, n. 17-28, n. 38; PL 32/815-825.

12 Boécio, De Trin. III; ed. Steward-Rand, 12-14.

13 Ou seja, tem uma tal natureza. 
tipo de coisa será o próprio quando, "que resta ${ }^{14}$ da adjacência ${ }^{15}$ do tempo"16?

(3) É questão assente que estes entes não são coisas de intenção segunda; logo, segundo estes mesmos filósofos alguns entes são constituídos por um acto do intelecto e nem tudo o que é constituido por uma operação do intelecto é uma coisa de intenção segunda.

(4) Mas não parece ser possível que o intelecto seja o princípio constitutivo de alguns entes.

(5) Em primeiro lugar, porque o intelecto é uma certa faculdade passiva cuja natureza não é a de fazer algo ${ }^{17}$, mas sim de sofrer ${ }^{18}$ : com efeito, segundo o Filósofo ${ }^{19}$ pensar $^{20}$ é uma certa paixão ${ }^{21}$.

14 Ou que se segue, obtém (relinquitur).

15 Adiacentia, por oposição a essentia. A questão que se coloca é pois a de saber o que é de facto a categoria do tempo (quando, em latim) se esta mais não é que aquilo que resta ou se obtém pela sua adjacência - ou seja, a sua existência junto a (por outras palavras: dependência) - em relação ao tempo.

${ }^{16}$ L. sex princ. IV, 33; ed. Minio Paluello - Dod, 42.

17 Ou seja, de agir.

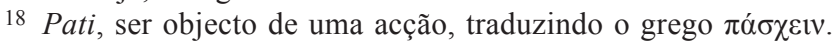

19 Aristóteles, De an. III, 4, 429a13-14; ibid., 429b24-5.

20 Intelligere. Termo polissémico de difícil tradução. Por intelligere, traduzindo o grego vo๕ĩv, pode entender-se pensar no sentido de conhecer pela razão, apreender pelo intelecto, conceber intelectualmente e até mesmo compreender de modo imediato (sem o auxílio dos sentidos). O termo é frequentemente explicado como significando intus legere (cf. por exemplo Tomás de Aquino, Summa theol. II-II, q. 8, a. 1, co.: nomen intellectus quandam intimam cognitionem importat, dicitur enim intelligere quasi intus legere.), ler no interior (de uma coisa), ou seja, captar a noção/essência/definição de uma coisa, pelo que o que está em causa é uma forma de conhecimento superior ao conhecimento sensível (cf. Tomás de Aquino, ibid.: Et hoc manifeste patet considerantibus differentiam intellectus et sensus, nam cognitio sensitiva occupatur circa qualitates sensibiles exteriores; cognitio autem intellectiva penetrat usque ad essentiam rei, obiectum enim intellectus est quod quid est, ut dicitur in III de anima.) A questão é porém mais complicada do que uma mera dicotomia pretensamente distinta entre os conhecimentos sensível e intelectivo puro, pois que para pensar o homem necessita das representações (phantasmata) das coisas, nomeadamente das representações enquanto formas abstraídas da matéria no acto de cognição; é certo que há alguns intelligibilia, entes inteligíveis, que - parece - nada devem à matéria (por exemplo, as formas geométricas), mas se os phantasmata ou representações implicam necessariamente uma abstracção da matéria, como parece ser o caso (o

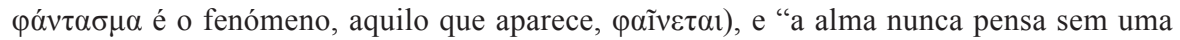

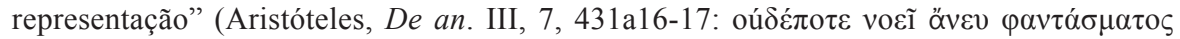
ท่ $\psi v \chi \eta ́)$, então pensar é também uma forma de sentir, ou de ser sujeito a sensações, isto é, uma forma de paixão. Isto põe em causa o conhecimento intelectivo puro, o papel do intelecto aparecendo como o de abstrair as formas da matéria e contribuir com os universais para o conhecimento das coisas individuais (cf. De an. II, 5, 417b17-23). Vê-se assim o quão traduzir intelligere - ou vo๕ĩv - por pensar é um faire avec, faute de mieux.

21 Passio, traduzindo o grego $\pi \alpha ́ \theta$ os. 
(6) Em segundo lugar, porque absolutamente todos os entes que são pela razão e pelo intelecto parecem ser coisas de razão e coisas de intenção segun$d a$, o tipo de entes que não são aqueles acerca dos quais se disse acima que são a partir de um acto do intelecto e são porém entes de intenção primeira classificáveis num género.

(7) Em terceiro lugar, porque de uma operação do intelecto nada se adiciona numa coisa ou acerca de uma coisa fora do intelecto, consistindo a entidade de tais entes apenas na $<$ sua $>$ apreensão.

(8) Em quarto lugar, porque assim como pelo intelecto se apreende algo com respeito a uma coisa, assim também pela imaginação; não se segue porém que uma coisa seja tal como é apreendida pela imaginação, ou que a partir disto ela tenha a noção de ente. Assim parece ser < também> acerca do intelecto, visto que pela sua apreensão as coisas não têm a noção de ente.

(9) Mas para refutarmos estes argumentos temos de saber que as causas são de dois tipos diferentes.

(10) Algumas são causas em termos da potência, como a matéria ou algo possuindo a noção e o modo da matéria. Embora nas coisas determinadas a $<$ sua $>$ matéria própria seja determinada de acordo com uma certa forma, como na natureza o mênstruo para os animais, nas coisas artificiais o ferro para a serra ${ }^{22}$, e por aí fora, tal é porém por acidente na medida em que a geração é a partir destas coisas. Em si $i^{23}$ é a geração a partir de um sujeito que é um ente em potência de acordo com a <sua > própria noção; por acidente algo forma-se a partir de uma forma ou de uma determinação ${ }^{24}$ que se encontra num sujeito. Digo por acidente em relação à existência da própria coisa que subsiste somente a partir do sujeito e da forma, quanto quer à acção de $\operatorname{criar}^{25}$ simples da coisa, quer à geração no tempo. Na medida, porém, em que essa acção de criar implica o movimento ${ }^{26}$ que é a partir de um determinado princípio para ${ }^{27}$ um determinado fim, a forma que existe no sujeito a partir do qual se faz a geração é em si mesma; pelo que de acordo com isto a matéria segundo a determinação de uma tal forma pertence à definição dos entes naturais.

(11) As causas em termos do acto, que são o fim, a forma e o eficiente, são diferentes $<$ das causas em termos da potência>. É evidente que estas são causas pelo facto de serem algo em termos de um certo acto. O fim importa a perfeição última do ente, o que é evidentemente em termos de um certo acto; a forma é de facto o acto do ente de acordo com a própria noção; o eficiente é na sua actualidade determinativo do ente em acto com relação ao próprio fim. Falo aqui do fim, da forma e do eficiente não no modo como eles se encontram

22 Ou seja, o mênstruo está determinado (tem a determinação) para se tornar num animal, e o ferro está determinado para se tornar uma serra.

$23 \mathrm{Ou}$ seja, essencial ou de modo essencial.

24 Ou disposição (dispositio, no original).

25 Factio; mais literalmente: a feitura de uma coisa.

$26 \mathrm{Ou}$ a mudança (motus, no original).

27 Com vista a; em direcção a. 
nas coisas naturais, que implicam o movimento e a matéria, mas no modo mais geral em que de acordo com uma qualquer sua noção eles se encontram nos entes separados, embora não pela mesma razão que no caso dos entes naturais, como diz Averróis acerca do fim em Sobre o Livro III da Metafísica ${ }^{28}$, e acerca do eficiente no princípio do livro IV de Do Céu e do Mundo ${ }^{29}$.

(12) A diferença destes três em relação uns aos outros considera-se de acordo com as diferentes noções de causar ${ }^{30}$.

(13) O fim é a causa de acordo com a noção do bom e do complemento em relação à qual uma coisa é; pelo que não é uma causa por constituir uma coisa, mas antes no modo de uma intenção ${ }^{31}$. Pelo que nem dá nem determina em relação a um ente os seus princípios, a partir dos quais ele é e nos quais subsiste, senão por suposição ${ }^{32}$; e isto tanto nos entes naturais como nos artificiais ${ }^{33}$, como o Filósofo mostra de modo bastante claro em muitas passagens ${ }^{34}$. O que faz com que o fim respeite mais imediatamente o próprio ente cuja perfeição importa do que os princípios desse mesmo ente, os quais esse mesmo fim não produz, nem tão-pouco a partir deles constitui esse ente senão, como se disse, por suposição ou por meio de uma intenção.

(14) A causa em termos da forma é-o de três modos diferentes. De um modo pela informação intrínseca de uma coisa, nomeadamente de acordo com o qual um acto é em si mesmo e pela sua essência o princípio intrínseco e a causa de um ente, como a alma nas coisas animadas. Algo é uma causa em termos da forma de um outro modo no qual a partir do próprio princípio se obtém por meio de um agente um acto e uma forma numa outra coisa por este princípio com respeito ao qual cada um deles se comporta como um objectos ${ }^{35}$, a saber, aquilo que é obtido a partir da outra coisa, e aquilo a partir do qual se faz essa obtenção ${ }^{36}$; e isto é propriamente a causa formal exemplar ${ }^{37}$. Num terceiro modo quando algo

28 Averróis, In Aristotelis Met. III, comm. 3; Venetiis, 1562, 41rC-E.

29 Averróis, In Aristotelis De caelo IV, comm. 1, Venetiis 1562, 234rA.

30 Rationes causandi.

31 Per modum intentionem <finis>, ou seja, com vista a um fim.

32 Ex suppositione $<$ finis $>$, ou seja, na suposição que um determinado fim deve ser alcançado.

33 Os entia artificialia são entes criados por meio da arte ou da técnica (ex.: uma casa), por oposição aos entes criados pela natureza; ainda numa outra acepção, os entia artificialia são entes de razão.

34 Aristóteles, Phys. II, 3, 195a23-5; Met. V, 2, 1013a32-3, 1013b25-7; De part. animal. I, 1, 639b19.

35 Mais propriamente, têm a noção de objecto (ratio obiecti ou ratio formalis obiecti), de acordo com a qual algo é formalmente (vs. materialmente) o objecto de uma faculdade específica; por exemplo, o homem, o cavalo e a pedra têm todos a mesma noção formal do colorido, o qual é o objecto da visão (cf. Tomás de Aquino, Summa theol. I, q.1, a. 3, co.).

36 Mais propriamente, uma derivação (deductio).

37 A causa exemplar é uma quinta causa - a juntar às quatro causas aristotélicas - introduzida pela escolástica para exprimir a crença de que os "modelos" de todas as coisas possíveis (que podem existir) pré-existem idealmente em Deus; esta causa separa 
se obtém a partir de outro ente em termos da forma de maneira a que a noção quiditativa de um seja obtida a partir da noção quididatitiva do outro; estes são os entes que pertencem ao último dos três modos enumerados no princípio deste tratado ${ }^{38}$. Digo que os modos mencionados são causas em termos da forma porque uma vez eliminadas do ente tanto as causas eficientes quanto as finais, se se considerar este somente de acordo com a noção de ser, então encontramos ainda uma certa dependência formal de um ente em relação a outra coisa, não decerto pelo modo do eficiente nem por meio de intenção e por suposição, o que é próprio do fim, mas por informaçã $o^{39}$, como se disse.

(15) A noção e o modo do eficiente são diferentes dos anteriores. Não é causa por intenção, como se disse acerca da causa final, mas determina em relação a um ente os seus princípios intrínsecos e a partir dos mesmos constitui $o$ ente de um modo mais - se assim podemos dizer - produtivo ${ }^{40}$; pelo que $a$ sua causalidade primeiro por natureza alcança os principios de um ente e por meio destes <alcança> o próprio ente. Graças ao que difere daquela que é a causa em termos da forma: a forma não se determina a si própria na matéria, encontrando-se em potência em relação àquilo que a determina, visto que em si mesma não é um ente completo, mas tão-somente aquilo que é composto a partir de si mesma e de um sujeito <é um ente completo>. Pelo que assim como a matéria em termos de sujeito existe em si mesma em relação a uma forma, do mesmo modo a forma existe em termos de informação em si mesma em relação ao eficiente. Pelo que o eficiente enquanto tal não pressupõe nem exige um outro eficiente nem ao causar se comporta de modo material e subjectivo com respeito ao qual $<$ modo $>$ produza uma outra coisa qualquer, que porém com respeito a todos os modos das formas se deve encontrar pela razão mencionada, tendo pelo contrário a noção de princípio activamente determinando para um ente os seus princípios e a partir destes constituindo o próprio ente ${ }^{41}$. Entendo aqui o eficiente

ainda a causalidade natural da causalidade divina e/ou intelectual na medida em que a causa exemplar é igualmente eficiente: o agente divino é simultaneamente o exemplar e a causa eficiente de um determinado efeito. A causa formal exemplar é uma espécie de compromisso entre esta causa exemplar e a causa formal contemplada por Aristóteles; mais precisamente, a causa formal exemplar, que mais não é que a ideia divina, é de facto um compromisso, exigido pela teologia cristã de modo a vincar a dependência da criatura em relação a Deus, entre a ideia platónica e a causalidade aristotélica. Contra Tomás de Aquino, que equaciona esta causa com Deus (cf. De veritate, q. 2, a. 3, s.c. 11; ibid., q. 3, a. 1, s.c. 3), Teodorico retira a causa formal exemplar deste contexto teológico, vendo-a a partir de um ponto de vista puramente metafísico: falamos de causa formal exemplar quando um agente "deriva" ou "transfere" uma forma de um ente para outro, ambos tomados como objectos.

38 Cf. 1,5 .

39 Leia-se in-formação, introdução de uma forma.

40 Executive.

41 Parafraseando: ao contrário da matéria e da forma, que existem em si mesmas em relação a algo que as determina (a matéria existe em si mesma como um sujeito em relação à forma e esta por sua vez existe em si mesma como in-formação com respeito ao 
de modo geral: tanto aquilo que leva o ente ao seu acto a partir dos próprios princípios como aquilo que causa a essência desses mesmos princípios cuja acção por movimento e transmutação é exigida na natureza por todo o agente.

(16) Vistos os modos das causas, temos agora de ver se o intelecto tem o carácter de uma causa com respeito a alguns entes, e, se tal for o caso, de acordo com que tipo de causa.

(17) Em primeiro lugar temos de saber que toda a coisa cuja entidade se encontra <ser> em si mesma e de modo simples na totalidade dos entes, se em si mesma e de acordo com a própria natureza tem alguma relação com algum <outro> ente, afirmo que um tal ente será igual a esse ente, ou um será de um qualquer modo a causa do outro, de acordo com o tipo da relação que se considera entre eles. Refiro-me a uma coisa cuja entidade se encontre $<$ ser $>$ em si mesma, excluindo os entes por acidente. Digo "de modo simples" para que se exclua o ente concreto ${ }^{42}$ enquanto tal; e de acordo com isto o ente em si mesmo e de modo simples é um ente segundo a espécie intencionado por si na natureza. Se este ente se relacionar com outro não por meio de uma qualquer faculdade capaz de comparar um com o outro, mas em si mesmo e de acordo com a própria natureza, isto não pode ser senão por causa de uma qualquer dependência real de um em relação ao outro. Uma tal dependência não se pode entender senão em termos de identidade ou de causa: uma vez removidos estes modos das coisas, todas as suas naturezas e determinações são realmente absolutas e independentes, não tendo uma relação natural recíproca.

(18) Quanto ao nosso intelecto, visto que pertence ao número dos entes mais formais da natureza, é evidente que a sua entidade é em si mesma. Ele não só é um ente de modo simples em termos da espécie de acordo com o modo dos entes geráveis e corruptíveis, mas tem ainda em cada indivíduo a maneira de ser do ente de modo simples: embora a sua natureza se conte em individuos diferentes, tal acontece-lhe enquanto intelecto ${ }^{43}$. Pelo que em todo o indivíduo ele é assim,

eficiente), o eficiente não necessita de mais nada além de si próprio: ele é em si mesmo um princípio determinante e constituinte do ente.

42 Ens ut nunc, o ente "aqui e agora", "incorporado", ou seja, o ente enquanto realidade corpórea existindo no tempo. Assim sendo, ser de modo simples é ser de modo puramente formal (ver parágrafo seguinte). Note-se que a expressão ens ut nunc é inabitual.

43 Trata-se aqui da rejeição da tese dita averroísta segundo a qual os intelectos agente e possível são os mesmos para toda a espécie humana, ou seja, todos os homens partilham de um mesmo e único intelecto agente e de um mesmo e único intelecto possível. Esta tese causou sensação no seio da filosofia escolástica, originando uma quantidade apreciável de escritos dedicados a esta disputa, com os filósofos cristãos de modo geral a defender a tese que cada indivíduo tem o seu intelecto agente bem como o seu intelecto possível; caso contrário, poder-se-ia concluir que "o homem não pensa", o que seria inaceitável do ponto de vista da teologia cristã. Mas esta "individualidade" implica que todo o indivíduo possuidor de um intelecto partilha do carácter formal único deste. Porém, a questão é bem mais complexa (ver nota 47 ). 
ou seja, singular e actual ${ }^{44}$, não porém concreto $^{45}$ segundo a sua própria noção na medida em que não se encontra $<$ ser $>$ concreto $^{46}$ por uma causa agente cuja causalidade implica movimento e transmutação $0^{47}$.

(19) Defendemos este modo do nosso intelecto, primeiro a partir da sua operação natural, depois a partir da própria noção de intelecto enquanto tal. Mas estas questões têm de ser tratadas noutro lugar ${ }^{48}$.

(20) Com efeito, o nosso intelecto tem em si mesmo e de acordo com a própria natureza uma relação essencial com os entes existentes. Entre as faculdades passivas e activas e os seus objectos considera-se uma relação essencial. Isto é mais evidente no caso do intelecto, o qual tem uma relação essencial com aquilo que é inteligível, como os sentidos $<$ têm $>$ com o sensível ${ }^{49}$, como diz o Filósofo no livro V da Metafisicica ${ }^{50}$, onde o Comentador diz que faz parte da essência do intelecto ter uma tal relação ${ }^{51}$. Logo, as coisas ou as quididades das coisas que são objectos do intelecto, ou são idênticas ao intelecto de acordo com o que se disse acima, ou haverá entre eles apenas uma relação de causalidade ${ }^{52}$. Mas $o$ nosso intelecto não é idêntico às coisas; resta logo apenas a relação em termos da causa e do causado.

(21) Entendamos aqui, por exemplo, coisas materiais compostas de matéria e de forma e as determinações e circunstâncias destas coisas. Mas estas coisas não têm o carácter de uma influência causal em relação ao intelecto, e falo aqui da influência que é essencial ${ }^{53}$. A razão para tal é que o intelecto é um ente incomparavelmente mais formal e simples do que o são estes entes. É necessário que

44 Nunc; o adjectivo actual exprime aqui a existência no tempo presente bem como a actualidade no sentido aristotélico.

45 Ut nunc.

46 Ut nunc.

47 Parafraseando: embora o intelecto seja individual (ou seja, cada indivíduo tem o seu próprio intelecto), sendo pois singular e actual, tal não implica que por isso ele não seja um ente de modo simples (puramente formal), pela razão que ele não é um ente concreto graças a uma qualquer causa que implique movimento e transmutação (por outras palavras: uma causa natural; ver Quadro 4 na Introdução). A intenção de Teodorico é de mostrar que há de facto uma dependência real entre o intelecto e os entes com os quais ele tem uma relação, e que esta é de causalidade (cf. De or. 5, 20 abaixo) - o intelecto causa os entes, ou seja, a realidade -, embora o intelecto, fora desta relação, seja um ente absoluto e independente (ver De or. 5, 17).

48 Teodorico de Freiberg, De intell. III, 8-9; ed. Mojsisch, 183-4.

49 Com a diferença porém que a relação essencial entre os sentidos e o sensível é uma relação de uma faculdade passiva com o seu objecto, enquanto a relação existente entre o intelecto e o inteligível é também e acima de tudo, como se verá, entre uma faculdade activa (o intelecto agente) e o seu objecto; enquanto faculdade activa, o intelecto "faz" (agit) o próprio objecto.

50 Aristóteles, Met. V, 15, 1021a29-b3; also De an. III, 4, 429a17-18.

51 Averróis, In Aristotelis Met. V, comm. 20; ed. Ponzalli, 176.

52 Cf. 5,17 acima.

53 Ou melhor, de uma causa essencial. 
as causas essenciais, que são as causas em termos do acto, tenham de antemão em si mesmas o seu causado graças a uma faculdade mais formal do que o é o próprio causado, caso contrário não teriam em relação aos entes o carácter de causa. E isto levou Aristóteles a ver o intelecto agente na criação ${ }^{54}$ das espécies inteligíveis, à qual uma faculdade inferior ao intelecto não tem acesso: com efeito, o agente é sempre mais nobre do que o paciente e o princípio <é sempre mais nobre $>$ do que a matéria, como diz o mesmo ${ }^{55}$, e como Agostinho diz em muitas passagens ${ }^{56}$. Se se considera uma qualquer causalidade entre o intelecto e estes seus objectos, é necessário que a mesma venha do lado do intelecto em relação às coisas, e não no sentido contrário ${ }^{57}$.

(22) Mas pode-se aqui averiguar racionalmente. Vemos de igual modo nas outras faculdades apreensivas, como nos sentidos, na imaginação, etc., que são entes mais formais do que os seus objectos, embora pertençam ao organismo vivo, e têm uma existência espiritual, ainda que num grau inferior ao do intelecto; é porém absurdo pensar que estas faculdades têm o carácter de uma causa com respeito aos seus objectos, sendo antes precisamente o contrário, como diz o Filósofo no livro II do Tratado sobre a Alma ${ }^{58}$.

(23) Mas deve-se dizer que a relação destas faculdades com os seus objectos não é a mesma que a do intelecto com os seus. Para a compreensão desta questão devemos ter em conta que as faculdades apreensivas são de dois tipos.

(24) Há aquelas cuja apreensão consiste em ser-se movido por algo que tem o carácter de um objecto cujo movimento, de uma natureza como que física, alcança o órgão do sentido através de um meio, <alcançando > em seguida a imaginação ${ }^{59}$. O que faz com que estes órgãos se encontrem numa determinação final ${ }^{60}$ de modo a que neles se produza a forma em acto do sentido e da representação ${ }^{61}$ graças a um princípio vital intrínseco mais formal por meio do

\section{Factio.}

55 Ibid., 430a18-19.

56 De musica VI, 4, n. 7; PL 32/1166; De Gen. ad litt. XII, 16, n. 33; PL 34/467.

57 Note-se a ausência de quaisquer considerações do âmbito teológico cristão nesta tese da causalidade do intelecto agente em relação aos seus objectos: Teodorico utiliza como auctoritates Aristóteles e Averróis, e Agostinho, se com efeito se trata de um teólogo, enquanto filósofo pode ser visto acima de tudo como fortemente influenciado pelo neoplatonismo que vai beber ao Estagirita esta tese da superioridade do agente em relação àquilo sobre o qual a sua acção recai.

58 Aristóteles, De an. II, 11, 424a1; ibid., II, 12, 424a21-3.

59 Imaginatio; ver abaixo.

60 Dispositio ultima, a disposição ou determinação para a recepção de uma forma específica; a "estrutura" final de um ente que lhe permite a recepção de formas específicas.

61 Ou da imaginação. Phantasia é um termo extremamente problemático na medida em que o seu significado oscila entre imaginação e representação. O problema radica em grande medida em Aristóteles, nomeadamente no uso que ele faz do termo grego $\varphi \alpha \nu \tau \alpha \sigma i ́ \alpha$ no De anima. O verbo paíveıv, mostrar, trazer à luz, tornar visível, explicar, tornar claro, etc., etimologicamente relacionado com o termo $\varphi \omega \varsigma$ ou $\varphi \alpha^{\prime} \varsigma \varsigma, l u z$, e especialmente a forma

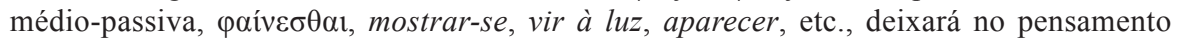


espírito que corre pelos nervos e que se origina por este princípio de modo a ser um instrumento de movimento e de sensação. E isto é claramente defendido pelo Filósofo no livro II do Tratado sobre a Alma ${ }^{62}$, nomeadamente no que diz respeito ao efeito das coisas sensíveis nos órgãos dos sentidos; o complemento final das formas sensíveis no modo que se referiu é discutido pelo Comentador na mesma passagem ${ }^{63}$. Diga-se isto sem opinião preconcebida de acordo com a opinião destes filósofos, com a qual Agostinho concorda em muitas passagens ${ }^{64}$.

(25) Quer assim seja, quer não, veremos contudo que as coisas têm o carácter de causa com respeito a estas faculdades actualizadas. Se as formas em acto dos sentidos vêm integralmente das coisas sensíveis, a questão em discussão é evidente por si mesma, embora de acordo com isto <só> dificilmente se possa defender a relação que se considera nesta questão entre a causa e o causado

ocidental dois termos fundamentais: o primeiro, paıvó $\mu \varepsilon v o v$, na raiz do movimento fenomenológico (cf. Heidegger, Ser e Tempo, Intr., 7, A) e o segundo, $\varphi \alpha v \tau \alpha \sigma i ́ \alpha$, comummente traduzido como imaginação. Porém, basta olhar para a etimologia acima para que esta tradução se torne suspeita; de facto, nem Plotino nem Avicena, no uso determinante que fizeram do termo, se inclinaram para esta tradução: para o primeiro, $\varphi \alpha v \tau \alpha \sigma i ́ \alpha$ era a faculdade que unificava todos os dados recebidos pela sensação, tornando-os acessíveis à alma (cf. Enéadas IV, 3. 29-30), e para o segundo, muito provavelmente influenciado mais ou

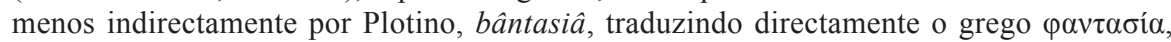
tinha o significado de senso comum, a faculdade receptiva dos dados impressos nos/pelos sentidos (cf. Liber de anima I, 5); em ambos os casos, o sentido de representação é ób-

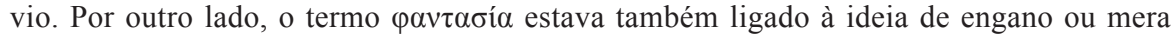
aparência, na medida em que se desconfiava que aquilo que aparece não o faz necessariamente de acordo com aquilo que é, tema "perene" da filosofia ocidental e que atinge um ponto de elaboração técnica importante em Kant e subsequentemente nos fenomenólogos. Nesta perspectiva, Plotino fala de $\varphi \alpha v \tau \alpha \sigma i ́ \alpha$ como o choque recebido pela parte irracional da alma por um objecto exterior (cf. Enéadas I, VIII. 15), mostrando-se desta feita mais fiel ao seu "mestre", Platão, para quem o sentido de simulacro marcava já o termo (cf. República II, 382c). Seja como for, em Aristóteles o termo parece corresponder sobretudo a representação, como se pode ver na seguinte afirmação: sem representação ( $\varphi \alpha v \tau \alpha \sigma i ́ \alpha)$, a alma não pensa (De an. III, 7, 431a16-17). Tomás de Aquino marca definitivamente a tradução do termo como imaginação em Summa theol. I, q. 78, a 4, co. (Ad harum autem formarum retentionem aut conservationem ordinatur phantasia, sive imaginatio, quae idem sunt, est enim phantasia sive imaginatio quasi thesaurus quidam formarum per sensum acceptarum.), embora seja claro que ele fala aqui de phantasia sive imaginatio num sentido de representação, mais do que daquilo que hoje entendemos por imaginação; phantasia/imaginatio é aqui a faculdade preservadora das imagens recebidas dos sentidos, sem as quais o organismo dotado de uma alma animal não agiria na ausência de objectos exteriores (por exemplo, sem a phantasia/imaginatio, um animal não procuraria alimento na ausência imediata deste).

62 Ibid., III, 3, 428b10-17.

63 Averróis, In Aristotelis De an. II, comm. 160; ed. Crawford, 415.

64 Agostinho de Hipona, De mus. VI, 5, n. 8; PL 32/1167-8; De Gen. ad litt. XII, 16, n. 33; PL 34/467; ibid., XII, 24, n. 51; PL 34/475. 
quanto à formalidade da causa em relação ao causado ${ }^{65}$. Se porém as coisas se passam de outro modo, como se disse, então, porque tanto as faculdades que produzem estas formas como as próprias formas produzidas são faculdades no corpo e $<$ faculdades $>$ orgânicas, não se formando nos órgãos $<$ dos sentidos $>$ senão no modo de movimento causado pelas coisas sensíveis num mesmo órgão, de acordo com isto as próprias coisas sensíveis têm o carácter de causa com respeito a eles. Tudo aquilo que é causa do sujeito - seja em fazendo<-o $>$ seja em determinando $<-0>$, graças ao qual o sujeito se encontre ${ }^{66}$ na determinação final que é a necessidade de receber uma forma que tem de ser produzida e existir no sujeito - é causa da forma na medida em que é a causa da união graças à existência da qual antes de mais a forma tem existência. E neste modo é evidente por que razão as faculdades são mais formais do que os seus objectos, embora os objectos com respeito a elas tenham o carácter de causa, como se disse ${ }^{67}$. Pelo que estas faculdades pressupõem nos seus objectos o acto formal e a existência especifica que compete a cada um de acordo com o próprio género e graças aos quais ${ }^{68}<$ cada um deles $>$ pode mover os órgãos destas faculdades e assim os objectos são apreendidos por essas mesmas faculdades. Tal é pois o modo $\boldsymbol{e}$ a relação das faculdades sensíveis com respeito aos seus objectos.

(26) Há porém um outro tipo de apreensão, cuja natureza não consiste em ser-se movido por um objecto, mas sim em ser uma certa forma simples que é um princípio de conhecimento na medida em que os próprios princípios são determinados em relação a esse objecto, a partir dos quais ele é constituído em termos da própria noção de objecto e em virtude do que ele é cognoscível ${ }^{69}$. E esta faculdade apreensiva é o intelecto, o qual tem assim o modo e o carácter

65 Viu-se acima $(5,21)$ que a causa tem de ser mais formal que o causado; se se considerar que o objecto dos sentidos é a causa da sensação, então tem de se admitir que o objecto é mais formal que a faculdade da sensação, o que não parece poder ser o caso, até por uma analogia com o intelecto e os seus objectos, os inteligíveis: os inteligíveis são os objectos do intelecto, tal como os sensíveis o são dos sentidos; ora, sabemos que o intelecto é mais formal do que os seus objectos, pois que ele é de facto dos entes mais formais da totalidade dos entes; a seguir à risca a analogia, os sentidos também teriam de ser mais formais do que os seus objectos.

66 Mais literalmente, seja feito (fiat).

67 Mas as coisas sensíveis podem de facto ser causa das formas a receber pelos órgãos dos sentidos na medida em que são a causa da união sujeito - objecto (receptor recebido), ou seja, elas causam de facto o sujeito ao determiná-lo quanto à recepção de uma forma específica da qual elas são também a causa, pois que a forma é em vista dessa união faculdade receptiva - forma a receber. Porém, as faculdades receptivas mantêm a sua maior formalidade face aos seus objectos, pois que é nelas que a forma tem de ser produzida e existir, embora a sua causa seja o próprio objecto.

68 Acto formal e existência específica.

69 Especificando: este outro tipo de faculdade apreensiva (o intelecto) não implica a passividade em relação a um objecto; pelo contrário, trata-se de uma faculdade activa, constituindo os princípios dos próprios objectos a partir dos quais eles têm a noção de objecto e graças aos quais eles são cognoscíveis. 
de causa com respeito ao seu objecto. Com efeito, os objectos não têm o carácter de uma causa com respeito ao intelecto em acto, tanto porque o movimento do objecto não chega até ele - pois que ele nem é um corpo nem uma faculdade no corpo ${ }^{70}$, mas sim algo separado de acordo com o Filósofo ${ }^{71}$-, como porque no acto de conhecimento não se pressupõe o objecto de acordo com a sua noção de objecto, graças à qual ele possa mover o intelecto e assim ter o carácter de uma causa, mas antes no acto de conhecimento o objecto começa a ter a noção própria de objecto ${ }^{72}$. O objecto do intelecto é a quididade, de acordo com o Filósofo ${ }^{73}$, ou a coisa em termos da sua quididade; porém, o intelecto de modo nenhum apreende esta quididade a não ser distinguindo e determinando os próprios princípios da coisa ${ }^{74}$, os quais o Filósofo chama as partes da forma ${ }^{75}$ que a definição significa. Só isto é conhecer ${ }^{76}$, ou seja, apreender uma coisa de acordo com a determinação desses princípios dela; de outro modo o intelecto não seria diferente da faculdade cogitativa, a qual pode despir a intenção de uma substância de modo que, despida na mesma < faculdade>, ela se mantenha despida de todas as imagens, como diz Averróis ${ }^{77}$, e de todos os apêndices acidentais ${ }^{78}$. E tal é a intenção da substância nessa disposição que de acordo com ela uma forma é produzida pela faculdade do intelecto agente no intelecto possível, graças à qual $<$ faculdade $>$ os seus princípios são determinados em relação à própria forma ou a uma coisa segundo a sua forma. E a partir disto a forma tem já a noção de quididade e a própria coisa tem uma existência quiditativa. E esta é a noção própria do objecto da faculdade intelectiva.

(27) Que assim o intelecto tem o carácter e o modo de um princípio causal com respeito ao seu objecto, tal é evidente. Pois que a relação de um destes com o outro é considerada em termos de causa, como se disse; a relação do intelecto em acto com o próprio objecto é em termos dos princípios do objecto, como já se disse; porém, os princípios de um ente enquanto tal não têm a actualidade desse mesmo ente e têm o modo do existente em potência na medida em que a

70 Nec est corpus nec virtus in corpore, "fórmula" extraída do De anima pela escolástica, nomeadamente para argumentar em favor da tese da incorruptibilidade do intelecto e para afirmar o seu carácter de ente simples e puramente formal.

71 Aristóteles, De an. III, 4, 429a24-7; ibid., 429b4-5; ibid., 5, 430a17.

72 Resumindo: os objectos não podem ter o carácter de causa com respeito ao intelecto porque (1) este é completamente separado e (2) só no acto de conhecimento o objecto começa a ter a noção ou natureza de objecto.

73 Aristóteles, De an. III, 6, 430b27-9.

$74 \mathrm{Ou}$ seja, é o intelecto que causa a própria quididade da coisa, por meio da qual ele a conhece.

75 Aristóteles, Met. VII, 10, 1035b34-1036a1; ibid., 11, 1036a26; ibid., $1036 \mathrm{~b} 5$.

76 Intelligere.

77 Averróis, In Aristotelis De an. III, comm. 6; ed. Crawford, 415.

78 A faculdade cogitativa (virtus cogitativa) mais não faz que abstrair as intenções das substâncias a partir da sensação; pelo contrário, a faculdade intelectiva (virtus intellectiva) cria a própria quididade das coisas que são objectos de conhecimento. 
partir deles se constitui aquilo que é o ente em acto de modo simples: logo, o ente pelos seus princípios não é causa de coisa nenhuma. É pois necessário que a causalidade se encontre no intelecto com respeito à coisa a partir dos seus próprios ${ }^{79}$ princípios, e não da parte da coisa pelos próprios ${ }^{80}$ princípios com respeito ao intelecto ${ }^{81}$.

(28) Além disso, como já se disse, o intelecto tem uma relação essencial com o objecto em termos dos seus ${ }^{82}$ princípios. Assim, a relação dos princípios com aquilo do qual são princípios é conforme ao tipo de relação pela qual o intelecto respeita a coisa constituída ${ }^{83}$ a partir dos seus princípios ${ }^{84}$. Mas a relação dos princípios com aquilo do qual são princípios é causal. Logo, a relação do próprio intelecto com esta coisa em termos dos seus princípios é causal. A inferência é evidente a partir do facto que assim como os princípios intrínsecos não têm uma relação causal com o ente do qual são princípios, a não ser enquanto se encontram numa relação de outra causa que determina estes princípios para $o$ acto completo do ente na medida em que eles não se podem determinar a si próprios, pelo que nada tem uma relação essencial com os princípios enquanto estes se encontram em potência para um tal ente constituido a partir deles excepto aquilo que determina causalmente esses mesmos princípios para o acto de um tal

79 Do intelecto.

80 Da coisa.

81 Parafraseando: sem o intelecto, os princípios do ente existem somente em potência, não sendo "causa de coisa nenhuma"; assim sendo, no acto de conhecimento a causalidade vem dos princípios do próprio intelecto. No seu tratado sobre o intelecto e os inteligíveis, De intellectu et intelligibili, Teodorico apresenta uma lista de doze princípios que evoca de maneira impressionante as categorias kantianas: (1) entidade, ou seja, o objecto do intelecto tem de ser um ente; (2) o verdadeiro, verum (o ente tem de se adequar ao intelecto, segundo a fórmula de Alberto Magno veritas est adaequatio rei ad intellectum); (3) os princípios primeiros (prima vel ex primis), mais especificamente, os princípios considerados por Aristóteles em Anal. Post. I, 2, 71b28-29; (4) proposições ou definições imediatas; (5) a noção a partir da qual o intelecto conhece uma coisa tem de ser melhor conhecida que a própria coisa; (6) a causa deve estar implicada na noção segundo a qual uma coisa é conhecida; (7) necessidade no sentido de invariabilidade; (8) necessidade no sentido de permanência; (9) eternidade (o intelecto só conhece aquilo que é eterno, ou seja, permanente e invariável); (10) predicação universal (o objecto do intelecto deve poder predicar-se de tudo e de todos, dicatur de omni et semper); (11) essencialidade (uma coisa é conhecida pela sua essência); (12) universalidade (o conhecimento sem qualificação e perfeito). Cf. De intell. III, 34.

82 Do intelecto e, logo, do objecto, ou seja, os princípios pelos quais um ente é um objecto do intelecto são princípios com os quais o intelecto determina o objecto enquanto tal.

83 Constituta.

84 Ou seja, a relação do intelecto com o objecto é uma relação dos princípios com aquilo do qual são princípios; mais especificamente, trata-se de uma relação de constituição, na qual o intelecto constitui o objecto de conhecimento. 
$e^{2} e^{85}$. A razão disto é que o ente em potência enquanto tal não respeita senão 0 acto formal para o qual ele é <determinado> como para o seu complemento e o acto que determina causalmente esta potência para o acto; o que na questão em discussão não é outra coisa que o intelecto com respeito ao seu objecto e aos seus princípios, como se disse.

(29) Não se põe nenhum obstáculo se alguém argumentar que esta relação pela qual o intelecto determina com respeito a uma coisa os seus princípios é apenas segundo o modo de conhecer ${ }^{86} \mathrm{e}$ que tal não tem o carácter de uma causa ${ }^{87}$.

(30) Deve-se porém saber que no intelecto o modo de conhecer é a razão de existir em acto 88 ; pelo que ao determinar em relação a um ente os seus princípios segundo o modo de conhecer $<o$ intelecto $>$ determina-os segundo a própria razão de $\operatorname{ser}^{89}$. E de acordo com isto $<o$ intelecto $>$ tem de certo modo o carácter e o modo de princípio causal com respeito ao seu próprio objecto enquanto este é um ente determinado e tem uma existência quiditativa.

(31) Além disso, nesta noção de homem que é a de animal racional encontramos uma distinção dupla. A destas partes formais, ou seja, animal $<\mathrm{e}>$ racional, entre si, e a desta noção a partir da coisa natural da qual ela é a noção própria, como a partir do homem. Mas a natureza não faz nenhuma delas: com efeito, a operação da natureza não termina senão numa coisa natural enquanto tal. Mas estas partes entre si juntamente com a coisa-sujeito são uma coisa natural. Logo, estas coisas são a partir do intelecto que, ao distinguir, as faz: neste caso distinguir é o mesmo que fazer ${ }^{90}$. Visto que pois estas partes são em si mesmas e $<$ são> princípios essenciais desta coisa que é um homem, é evidente, a partir daquilo que se disse há pouco, que o intelecto tem o carácter de princípio causal com respeito às coisas ou aos <seus> próprios objectos, e não o contrário.

(32) Pode-se ainda deduzir um tal carácter a partir daquilo que já se disse. Dois entes que se encontrem numa relação tal que ser um deles é ser o outro não só no modo de uma inferência lógica, mas em termos de identidade, o que quer que seja que tem o carácter de princípio e causa com respeito a um deles

85 Parafraseando: a relação dos princípios com aquilo do qual são princípios (um ente em acto) só é uma relação causal no caso de um agente que determina esses mesmos princípios para o acto de um ente; os princípios em si mesmos, mesmo se intrínsecos, não são causais na medida em que não se podem determinar a si mesmos com respeito à actualização do ente do qual são princípios.

86 Modus intelligendi; esta expressão pode também ser traduzida como "modo de entender", "modo de pensar", ou ainda "modo de conceber" em contextos em que o aspecto intelectivo seja mais saliente que o cognitivo: aqui trata-se do modo pelo qual o intelecto conhece os seus objectos, os quais só o são precisamente no acto de conhecimento, como se viu.

87 Ratio causandi.

88 Por outras palavras, ser é ser conhecido; veja-se a fórmula berkeleyana segundo a qual ser é ser percebido, esse est percipi.

89 Ratio essendi.

90 Efficere; note-se aqui a alusão à causa eficiente. 
tem-no com respeito ao outro. A razão para tal é que estes entes ou são idênticos de todas as maneiras, ou um é a noção do outro ou pertence à noção do outro, por exemplo, ser um homem é <o mesmo que $>$ ser um animal e ser um animal racional é $<$ o mesmo que > ser um homem. Pois que o nosso intelecto tem o carácter de princípio e causa com respeito à noção deste homem, que é a de animal racional, como se disse, ele tem $<0$ mesmo carácter $>$ com respeito ao próprio homem, nomeadamente na medida em que este tem existência de acordo com esta noção, uma existência que é quiditativa, como se disse $\mathrm{e}^{91}$. E isto está de acordo com aquilo que o Comentador diz e defende ${ }^{92}$, a saber, que a matéria primeira recebe formas particulares ${ }^{93} \mathrm{e}$ individuais, o intelecto porém $<$ recebe $>$ formas de um modo simples ${ }^{94}$. A intenção de cuja opinião já se viu acima.

(33) E por causa disto o intelecto conhece ${ }^{95}$ por meio das formas que recebe, $<$ mas $>$ não graças à matéria primeira. É questão assente que todas as formas que existem na natureza gerável e corruptível são particulares e individuais. Ora, o objecto do intelecto nãa é o ente particular ${ }^{96}$, mas sim o ente de um modo simples. Visto que a natureza nas coisas geráveis e corruptíveis não faz existir em acto senão os entes particulares e individuais, ela cria ${ }^{97} \mathrm{o}$ ente de um modo simples somente por meio de uma criação ${ }^{98}$ de entes individuais ou por meio de uma continuação sucessiva, pelo que o ente de um modo simples tomado completamente em si mesmo encontra-se em potência nestas coisas e, na medida em que pode ser abstraído delas - se chamarmos o ente de um modo simples o universal que é abstraído das coisas individuais, ou se chamarmos ente de modo simples a espécie que contém todos os seus indivíduos ${ }^{99}$-, não tem existência na natureza senão em potência por meio da continuação sucessiva dos indivíduos; mas visto que o ente de um modo simples, que é o objecto primeiro do intelecto, é um ente em acto - de outro modo não teria o carácter de objecto -, um tal ente tem a $<$ sua $>$ entidade a partir da operação do intelecto. E isto é aquilo que

91 Tese fundamental - e idealista - deste tratado: na medida em que as partes da noção de uma coisa natural têm a sua causa no intelecto, e visto que a partir desta noção essa coisa tem uma existência quiditativa (ou seja, a essência é o mesmo que a existência), o intelecto é causa da própria coisa. O carácter "revolucionário" da tese é enfatizado pelo facto de o intelecto de que aqui se fala ser o intelecto humano (intellectus noster): pelo pensamento, no acto de conhecer, o homem cria a realidade, parece ser a tese de Teodorico.

92 Averróis, In Aristotelis De an. III, comm. 5; ed. Crawford, 388.

93 Hae, à letra, estas.

94 Veja-se o modo algo "suspeito" como Teodorico se apoia em Averróis para defender esta tese idealista: Averróis apenas diz que o intelecto recebe formas simples, ou seja, universais, seguindo assim o pensamento de Aristóteles expresso no De anima.

95 Intelligit.

96 Ens hoc ut hoc, literalmente, este ente enquanto isto.

97 Facit.

98 Factio.

99 Ou seja, falamos de universal ou espécie no caso de o ente simples que pode ser abstraído das coisas particulares consideradas como partes de um grupo específico de entes. 
se diz de um modo geral ${ }^{100},<$ a saber,> que o intelecto produz a universalidade nas coisas. De acordo com isto, ele constitui todas as coisas ${ }^{101}$ numa existência quiditativa a partir da $<$ sua $>$ própria noção ${ }^{102}$.

(34) Esta maneira de criar ${ }^{103}$ é análoga à operação da natureza. Assim como na natureza uma coisa é pelo seu acto formal em si mesma o princípio de uma operação causal que em si termina por um lado num ente constituído pela natureza, por outro lado nos princípios intrínsecos do ente como graças ao que algo é constituído, assim no intelecto a forma que é em acto é o princípio de uma operação inteligível ${ }^{104}$ que termina em si mesma e principalmente por um lado no ente em termos da sua quididade, por outro lado nos princípios deste ente nos mesmos termos ${ }^{105}$ como naqueles graças aos quais algo é ${ }^{106}$. Tal como na natureza além das coisas referidas se encontram em algumas coisas causais certas determinações naturais e formas acidentais graças às quais se determina a causalidade tal <que é a> da causa com respeito ao seu causado, como é a quantidade, o movimento local, a luz e as coisas semelhantes ${ }^{107}$, do mesmo modo no intelecto se encontram certos modos análogos a estes que são certas formas existindo da parte do intelecto que determinam uma operação inteligível. E estas são as coisas de razão que são coisas de intenção segunda.

(35) Que o intelecto tem o modo e o carácter de princípio causal com respeito aos entes no modo anterior, tal parece ser sugerido pelo Filósofo no livro IV da Metafísica ${ }^{108}$, onde diz que a noção que a palavra ${ }^{109}$ significa é a definição e que de acordo com isto as intenções e as significações das palavras são diferentes. É questão assente que nada é mais formal na significação de uma palavra que a própria coisa significada de acordo com a noção referida. Isto parece ser o caso segundo a intenção de Agostinho que, falando acerca do conhecimento intelectual

100 Averróis, In Aristotelis De an. I, comm. 8; ed. Crawford, 12; Tomás de Aquino, De ente IV.

101 Intellectus agit universalitatem in rebus, "fórmula" fundamental do pensamento árabe e da "Escola de Colónia", traduzível de forma menos literal mas mais apropriada como "o intelecto universaliza as coisas".

102 A palavra-chave é aqui constitui, um termo que, em relação quer ao objecto de conhecimento quer à própria realidade, se tornará corrente somente na terminologia filosófica idealista. Note-se ainda que Teodorico diz agora explicitamente que o intelecto constitui todas as coisas numa existência quiditativa, o que é surpreendente, uma vez que atrás dissera que ia demonstrar como o intelecto é princípio causal de alguns entes.

103 Modus factionis.

104 Ou melhor: intelectual. As operações da "alma nobre" eram em número de três, a saber, animal, intelectual e divina (cf. Tomás de Aquino, Super de Causis, 1. 3).

$105 \mathrm{Ou}$ seja, em termos de quididade.

106 Ver Introdução, Quadro 5.

107 Cf. 2,3 acima.

108 Aristóteles, Met. IV, 7, 1012a23-24.

109 Nomen; mais propriamente, substantivo. 
actual, o qual ele diz ser o verbo ${ }^{110}$, fala nos seguintes termos no livro IX.1 de $A$ Trindade, no capítulo $10^{111}$ : De um modo chamam-se verbos [= palavras] as coisas que contêm as durações temporais em sílabas, quer eles sejam pronunciados ou $<$ meramente> pensados; de outro modo tudo aquilo que é conhecido chama-se um verbo impresso no espírito enquanto pode ser proferido e definido de memória." E abaixo"112: "Defino o que é a intemperança e isto é o seu verbo." Anselmo diz no capítulo 10 do seu livro Monologion ${ }^{113}$, uma opinião que ele toma acima de tudo do livro do beatífico Agostinho A Trindade: "De um modo digo 'homem' quando por meio desta palavra ${ }^{114}$ significo aquilo que é um homem, de outro modo quando penso a mesma palavra sem a pronunciar, de outro modo <ainda $>$ quando a mente contempla esse mesmo homem seja por uma imagem do corpo, seja pela noção. Por meio de uma imagem do corpo, como quando se imagina a sua figura sensível, pela noção de facto como quando $<$ a mente $>$ pensa a sua essência universal que é a de animal racional mortal."

(36) Isto também se pode aceitar assim sem ser preciso raciocinar ${ }^{115}$. Vemos com efeito não só num tipo diferente, mas também no mesmo tipo de causa, como no caso das causas eficientes, que um e o mesmo ente é produzido a partir de várias causas de tal modo que é integralmente produzido por qualquer uma delas. E embora o ente produzido a partir de diversas causas seja o mesmo na realidade, ele é porém diferente pela razão, de acordo com o que é reduzido às $<$ suas $>$ diferentes causas, como por exemplo uma coisa gerada. Em toda a coisa e em toda a operação natural a causalidade é inseparável da causa primeira, segundo os filósofos ${ }^{116}$; precisamente como é a primeira, é a mais simples, e por isso a mais eficaz pelo facto de ser a mais formal. A este modo de causar chamam eles criação ${ }^{117}$, embora não pela mesma razão pela qual se fala de criação entre os teólogos; pelo que no Livro das Causas se diz que "a primeira das coisas criadas é o ser." ${ }^{118}$ Com efeito, cada ente, na medida em que a causalidade da

110 Verbum; termo de tradução problemática, na medida em que pode significar pala-

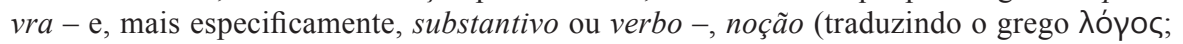
cf. por exemplo Agostinho de Hipona, De div. quaest., 46, 2; PL 40/30; ibid., 63; PL 40/54) e ainda, intimamente relacionado com estas duas traduções, o Verbo divino. No contexto do pensamento agostiniano aqui em causa traduzimos verbum como palavra quando o aspecto linguístico é o mais relevante, e como verbo quando noção parece corresponder melhor àquilo que Agostinho quer dizer.

111 Agostinho de Hipona, De trin. IX, 10, n. 15; PL 42/969.

112 Ibid.

113 Anselmo, Monolog. 10; ed. Schmitt, 1, 25.

114 Nomen.

$115 \mathrm{Ou}$ seja, de forma intuitiva (ex.: conhecimento dos primeiros princípios); o conhecimento divino e o dito angélico seriam exclusivamente deste tipo (cf. por exemplo Tomás de Aquino, Summa contra Gentiles I, 57).

116 Liber de causis, prop. 1; ed. Pattin, 134-8.

117 Creatio.

118 Ibid., prop. 37; ed. Pattin, 142. 
causa primeira o afecta ${ }^{119}$, é considerado um ente ${ }^{120}$, que é a primeira e a mais formal de todas as intenções. Uma coisa gerada é um ente na medida em que a causalidade do primeiro princípio a afecta; mas na medida em que a causalidade da causa que pertence a um segundo tipo - especificamente da causa que gera de modo natural - a afecta, segundo isto considera-se um ente natural, para falar mais correctamente, na medida em que nesta coisa a passagem da potência ao acto pelo movimento do gerador é tomada em consideração. É questão assente que este ente é integralmente um ente e que é de igual modo integralmente um ente natural pela razão já referida; pelo que é integralmente produzido a partir do primeiro princípio e <é $>$ integralmente $<$ produzido $>$ a partir do gerador, e nenhuma destas causas é supérflua na causação deste mesmo ente. E se se conceber que uma delas se poderia remover mas de um modo tal que a causalidade da outra $<$ causa $>$ se manteria, aquela cuja causalidade se manteria produziria efectivamente o mesmo ente, como há um exemplo apropriado nas Escrituras ${ }^{121}$ na criação dos primeiros entes individuais naturais que não passaram da potência ao acto pelo processo da geração ${ }^{122}$.

(37) Assim como uma coisa gerada é integralmente a partir do princípio primeiro na medida em que é um ente, de acordo com o que a partir do mesmo <princípio> lhe são determinados os princípios de ser quanto à essência dos princípios, também essa mesma coisa segundo a existência natural se encontra ser e é integralmente gerada por um gerador na medida em que lhe são determinados os princípios de um outro modo, nomeadamente em termos da potência e do acto ${ }^{123}$. De igual modo essa mesma coisa segundo a $<\mathrm{sua}>$ existência quiditativa é a partir da operação do intelecto, de acordo com o que lhe são determinados os princípios de um outro tipo, a saber, aqueles que são as partes da forma que é a quididade da coisa significada pela definição. E assim ela é integralmente a partir de um acto do intelecto, tanto como a partir das causas anteriores, mas por noções diferentes, como se disse, embora esta coisa se possa encontrar na natureza fora do intelecto, como se disse acerca das primeiras.

(38) Note-se porém daquilo que se disse que entre os filósofos a noção de ente enquanto ente varia. De um modo diz-se que uma coisa tem a noção de ente na medida em que se reduz ao princípio primeiro de todos os entes assim como

119 Mais literalmente: desce até/sobre ele (descendit in).

$120 \mathrm{Ou}$, o que é o mesmo, é considerado como sendo, como tendo existência quiditativa.

121 Gen. 1, 11-31.

122 Ou seja, Teodorico argumenta que as coisas criadas segundo as Escrituras foram-no por uma única causa (a causa divina), mas não deixaram por isso de ser entes completos, nomeadamente entes naturais. Note-se como, num tratado em que referências de carácter teológico são praticamente nulas, neste brevíssimo passo Teodorico apela para a autoridade das Escrituras. Oddly enough? Veja-se o parágrafo $(5,38)$.

123 Ou seja, e continuando a argumentação do parágrafo anterior, uma coisa tomada integralmente em si mesma é um ente pelo princípio primeiro e é uma coisa natural pela acção de um gerador na natureza. 
à sua causa, como aqui se disse ${ }^{124}$. De outro modo fala-se do ente enquanto ente na medida em que cada ente depende dos seus princípios intrínsecos, como se disse acima na investigação do segundo modo de principiar uma coisa ${ }^{125}$.

(39) Há porém quem tenha dúvidas em relação ao que se disse, a saber, que a mesma coisa que é constituída por outras causas naturais seja criada ${ }^{126}$ por uma operação inteligível do intelecto. Uma tal coisa no modo referido não tem uma existência quiditativa senão enquanto existe no intelecto e enquanto é inteligível, e não tem esta existência em si mesma fora do intelecto, ao que parece: a existência quiditativa não parece ser possivel senão no intelecto pelo facto que uma coisa não tem este modo a não ser quando os seus próprios princípios lhe são determinados como tais pelo intelecto ${ }^{127}$.

(40) Mas deve-se dizer que tal como no caso dos sentidos se verifica que $o$ sensível enquanto sensivel se diz de três modos a partir da faculdade de duplica$c_{c} \tilde{a} o^{128}$, assim o inteligível se diz no caso do intelecto. De um modo diz-se sensível enquanto sensivel a coisa existente num órgão dos sentidos na medida em que ela existe nesse órgão; e de acordo com isto não tem o carácter de objecto com relação ao órgão da sensação, mas deste modo uma coisa existe num órgão dos sentidos como intenção, forma ou semelhança da coisa percebida ${ }^{129}$ que existe fora desse órgão. De um outro modo <algo $>$ diz-se sensivel enquanto sensivel na medida em que nele termina a operação que é segundo um determinado sentido; $e$ assim não é diferente de dizer sensível enquanto sensivel senão enquanto algo é apreendido pelos sentidos. Num terceiro modo diz-se de algo que é sensivel enquanto sensivel enquanto nesse mesmo sensivel se encontra a noção e a causa por meio da qual é apreendido pelo órgão da sensação.

(41) E estes dois últimos são modos do objecto desse mesmo órgão dos sentidos que tem de se encontrar fora desse órgão. Com efeito, toda a forma que segundo a sua própria noção é uma forma noutra coisa e que, de acordo com isto, é o princípio de uma operação qualquer na medida em que é uma forma noutra coisa, é tal que a sua operação não termina senão em algo fora de si, caso contrário seguir-se-ia que o mesmo de acordo com o mesmo mover-se-ia a si próprio e o mesmo estaria < simultaneamente $>$ em potência e em acto com respeito a si próprio; o que é impossível. Assim, o sensível enquanto sensível na medida em que a operação sensível termina nele, na medida em que nele se encontra seja a noção, seja a causa por meio da qual ele é apreendido por um

124 Cf. introdução à questão em 1, 2 acima; primeira abordagem em 1, 13.

125 Cf. introdução em 1, 3 acima; tratamento em 1, 7-12.

126 Fieri.

127 Pode-se com efeito aceitar que uma coisa tem existência quiditativa graças a uma operação do intelecto, mas somente enquanto é pensada; fora do intelecto, ela pode não existir, sendo pois um mero ente de razão (ens rationis). Ora, este é precisamente o argumento que Teodorico quer refutar.

128 Vis reduplicationis.

129 Res sensata. Utiliza-se aqui percebimento como sinónimo de sensação, a recepção de impressões pelos sentidos. 
órgão dos sentidos, tem de se encontrar fora desse órgão. E é questão assente que então ele não se encontra senão na própria coisa percebida.

(42) O mesmo se deve dizer daquilo que é o inteligível enquanto inteligível, nomeadamente que de um modo designa a intenção de uma coisa ou a forma no intelecto por meio da qual a coisa é conhecida; e desta maneira não se encontra fora do intelecto nem tem o carácter de objecto. De outro modo o inteligível enquanto tal é esta própria coisa fora do intelecto na medida que nela termina a operação inteligível. De um terceiro modo diz-se o inteligível enquanto tal na medida em que nele se encontra a noção pela qual pode ser conhecido: e isto é na medida em que tem uma existência quiditativa.

(43) Visto que estes dois últimos são modos de uma coisa fora do intelecto, e porque uma coisa não adquire uma existência quiditativa senão por uma determinação do intelecto a partir dos $<_{s e u s}>$ próprios princípios no modo referido, é evidente que o intelecto tem de certo modo o carácter de um princípio causal com respeito às coisas ${ }^{130}$.

(44) Pode-se contudo ver de acordo com isto que tipo de causa se considera aqui. $O$ intelecto em acto não tem o carácter da matéria com respeito às coisas $^{131}$ : é com efeito uma forma e um ente em acto mais formal do que a própria coisa que é conhecida. Ele não é nem uma causa segundo a forma, visto que não é uma forma informando ${ }^{132}$ uma coisa por inerência ${ }^{133}$, nem é uma forma em termos de exemplar ou de ideal ${ }^{134}$, propriamente falando. Falo do intelecto especulativo com respeito às coisas especulativas; a razão disto é que o intelecto em acto não tem o carácter de objecto para a imitação do qual uma coisa seja exemplificada por um qualquer terceiro exterior a ambos fazendo tal, o que é próprio das formas exemplares e exemplificadas. Isto convém às formas das quais uma é quidificada a partir de outra, sendo que tal é feito por um terceiro agente com respeito ao qual ambas têm o carácter de objecto; e por isso neste modo $<_{0}$ intelecto $>$ não tem o carácter de causa formal com respeito

130 Reconstruindo o argumento de Teodorico:

(1) O inteligível enquanto inteligível tem o carácter de um objecto do intelecto quando a coisa conhecida se encontra fora do intelecto.

(2) Tal pode ser de dois modos:

(2.1) O inteligível é aquilo no qual termina a operação inteligível.

(2.2) O inteligível é aquilo no qual se encontra a noção pela qual é conhecido, ou seja, aquilo que tem uma existência quiditativa.

(3) Uma coisa não adquire uma existência quiditativa senão por uma determinação do intelecto a partir dos seus próprios princípios.

(4) Logo, o intelecto tem de certo modo o carácter de um princípio causal com respeito às coisas.

131 Ou seja, o intelecto não é uma causa material com respeito às coisas conhecidas.

132 Leia-se in-formando, ou seja, introduzindo uma forma.

133 Por outras palavras, o intelecto não é uma causa formal.

$134 \mathrm{O}$ intelecto também não é uma causa formal exemplar. 
às coisas ${ }^{135}$. Mas também não é propriamente um princípio no modo de um fim $^{136}$. Falo aqui da operação pela qual ele apreende a quididade das coisas: com efeito, em si mesmo e à maneira de uma produção ${ }^{137}$, por assim dizer, ele determina com relação a uma coisa os seus princípios formais e constituia a partir deles ao seu modo e não por intenção ou por suposição, o que é próprio da causa final. A sua causalidade primeiro alcança estes princípios do ente e a partir destes o próprio ente. Mas a perfeição do fim comporta-se de modo inverso com relação ao ente e aos seus princípios, como se disse acima ${ }^{138}$.

(45) Resta pois, de acordo com o que se disse, que o intelecto com respeito às coisas primeiramente e em si mesmas inteligíveis tem o carácter e o modo de uma causa eficiente. Mas porque o eficiente não age senão com um fim em vista, segue-se que lhe pode ser atribuído o carácter de causa final, na medida em que graças a uma operação inteligivel um homem adquire a perfeição que lhe é própria, a de homem enquanto homem. Quero dizer com isto que o intelecto ao constituir as quididades dos entes nas coisas especulativas no modo referido age com um fim em vista, não decerto sempre por deliberação e conhecimento prévio do fim, mas num certo modo natural, como certos outros entes tendem para os seus fins sem uma concepção prévia dos mesmos. E por isso não é necessário que à definição dos entes que são a partir do intelecto pertença a causa final, como se poderia objectar.

(46) Considera-se na constituição dos entes no modo anterior uma certa diferença, processo e ordem.

(47) Com respeito a certos entes o intelecto opera de tal modo que não lhes dá ser aquilo que são enquanto são entes e entes naturais - segundo estas noções estes entes são a partir de outros princípios naturais, como se disse -, mas produz neles a entidade, de acordo com o que eles são algo específico e têm uma existência quiditativa, o que é $<0$ mesmo que $>$ constituir estes entes integralmente, mas de acordo com uma noção diferente das outras referidas. E estes entes pertencem a uma substância e graças a estas são naturalmente

135 Teodorico desenvolve este último ponto segundo o qual o intelecto não é uma causa formal exemplar: a relação causal exemplar entre a causa exemplar e o efeito exemplificado pressupõe um terceiro interveniente, um agente que trate ambas as formas - a exemplar e a exemplificada - como objecto; ora, o intelecto em acto não tem o carácter de objecto. Trata-se aqui do intelecto especulativo ou teórico, meramente contemplativo e cuja operação visa apenas o conhecimento, sem ter em vista a acção, do foro do intelecto prático ou operativo; trata-se de uma dicotomia fundamental para o pensamento latino (cf. por exemplo Tomás de Aquino, Summa theol. I, q. 19, a. 4, ad 4; ibid., q. 79, a. 11, co.) que tem a sua origem no pensamento aristotélico (ex.: De an. III, 9, 432b27: ò $\mu$ غ̇v

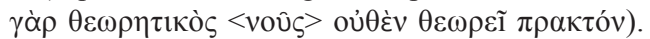

$136 \mathrm{O}$ intelecto também não é uma causa final; em seguida Teodorico explica sucintamente este ponto.

137 Per modum executionis.

138 Cf. 5, 13-14. 
concretos $^{139}$, como as quantidades, as qualidades e coisas tais que são princípios de uma operação natural ${ }^{140}$.

(48) Depois, com respeito a estes entes naturais o intelecto produz certos entes como certos modos de tais entes, e isto à maneira de medida, de relações ou de circunstâncias, como se disse acima ${ }^{141}$. Tanto a sua entidade completa como aquilo que são o que são com respeito àquilo que principalmente se significa pelo termo, são de um modo completivo por uma operação do intelecto.

(49) Há ainda outros entes que com relação aos anteriores têm o carácter e o modo de propriedades. A sua noção comum é a de que os princípios que principiam uma coisa enquanto ela é algo específico principiam estes entes na medida em que eles são com vista ao ente específico; e de acordo com isto têm o carácter de propriedades e de paixões essenciais. E estas são de dois modos. Se se tomar a noção definitiva à qual se reduzem as partes da quididade a partir dos princípios intrínsecos de uma coisa enquanto ela é um ente de modo absoluto, neste modo aqueles entes que de acordo com esta noção inerem como próprios tomam a sua entidade de uma operação do intelecto, como se disse acima na investigação do primeiro tipo de entes do terceiro modo ${ }^{142}$. Mas se as causas naturais de uma coisa, a saber, as causas eficiente e final, constarem da noção definitiva, então os entes que de acordo com esta noção inerem como próprios podem importar uma coisa natural; mas então diz-se que uma tal coisa é um ente natural e uma propriedade de um ente natural, como o frio e o húmido da água, o seco da terra, etc., por outras razões ${ }^{143}$.

(50) Há ainda outros entes que, de acordo com aquilo que são, são a partir de uma operação natural; porém, o intelecto, na medida em que os constitui na sua existência quiditativa, produz neles um certo novo modo de ser, como no caso dos entes que são puramente matemáticos, ou seja, aqueles sobre os quais o matemático e o geómetra se debruçam. O que faz com que de acordo com este modo de ser não só não sejam substâncias mas também não sejam disposições

139 Ou seja, não são entes puramente abstractos ou meros entes de razão, mas sim entes que de algum modo se encontram ligados à matéria.

140 Trata-se aqui dos entes do Tipo II longamente tratados em 2, 18-33 (cf. ainda Quadro 3).

141 Trata-se agora do terceiro tipo de entes tratado em 2, 34-54 (cf. Quadro 3).

142 Cf. 2, 8-17 acima. Este é o modo em que se tomam em consideração na noção definitiva de uma coisa somente os princípios intrínsecos, ou seja, um modo meramente formal.

143 Este modo de análise difere do anterior na medida em que à definição de uma coisa pertencem as suas causas naturais (cf. Modo 1 no Quadro 3). No primeiro caso, os entes que inerem numa substância ou ente natural como próprios são a partir de um acto do intelecto; no segundo caso são a partir de uma operação natural e são eles próprios entes naturais. Por exemplo, faz parte da definição da substância água enquanto ente natural o ser fria e húmida; logo, o frio e o húmido, propriedades dessa substância, são também eles entes naturais. 
ou acidentes de substâncias; pelo que ao considerá-los eles abstraem de todo o ente natural e dos princípios naturais enquanto tais ${ }^{144}$.

(51) Daqui se segue que, assim como nas coisas naturais os entes que são anteriores de modo simples são anteriores à natureza pelo facto que estes entes são algo de acordo com a natureza e a partir de uma operação natural, do mesmo modo nestes entes abstractos ${ }^{145}$, porque de acordo com este modo de ser são a partir de uma operação do intelecto, sendo excluídos deles todos os princípios naturais enquanto tais, os entes, digo, que neles são anteriores de modo simples de acordo com a existência que têm, são anteriores no intelecto ${ }^{146}$. E se se diz que estes entes são anteriores à natureza, não se toma aqui a natureza no sentido das coisas físicas ou das coisas metafísicas, as quais são coisas naturais de facto tanto de acordo com a <sua> existência como de acordo com o modo como são consideradas, mas diz-se que são anteriores à natureza, isto é, de um modo natural de acordo com este modo de ser que têm a partir de um acto do intelecto na medida em que são entes abstractos ${ }^{147}$. Por exemplo, ao triângulo, na medida em que é um ente natural, não convém em si mesmo ter um ângulo extrínseco; como é evidente, se se conceber um triângulo equilátero inscrito no

144 Teodorico introduz um novo tipo de entes - as entidades matemáticas (números, figuras geométricas, etc.) - que, embora produzidos por uma operação natural, são constituídos pelo intelecto na sua existência quiditativa segundo um novo modo de ser de acordo com o qual se encontram completamente separados dos entes naturais e dos princípios que se encontram na sua origem. Em termos do Quadro 3, estes entes parecem pertencer ao tipo das inteligências (cf. Modo 1 no Quadro 3).

145 Contrastar com os entes concretos referidos em 5, 47. Chama-se a atenção para o facto de o ente abstracto ser considerado invariavelmente mais nobre e superior, até porque a abstracção é idêntica à simplicidade. Esta concepção terá consequências importantes a nível da polémica entre os intelectualistas e os voluntaristas (cf. Tomás de Aquino, Summa theol. I, q. 82, a. 3, co.: Obiectum enim intellectus est simplicius et magis absolutum quam obiectum voluntatis, nam obiectum intellectus est ipsa ratio boni appetibilis; bonum autem appetibile, cuius ratio est in intellectu, est obiectum voluntatis. Quanto autem aliquid est simplicius et abstractius, tanto secundum se est nobilius et altius. Et ideo obiectum intellectus est altius quam obiectum voluntatis.)

146 Note-se a argumentação de Teodorico: há, quer nos entes naturais, quer nos completamente abstractos, entes que são anteriores à natureza; como só há apenas duas causas, a natureza ou o intelecto, tudo o que é anterior à natureza tem forçosamente de ser causado pelo intelecto.

147 Teodorico complica agora a argumentação acima ao distinguir a natureza de que aqui se trata daquela dos físicos e dos metafísicos; as coisas naturais num sentido físico e metafísico são-no de facto tanto de acordo com a sua existência como de acordo com o modo como são consideradas. Como se verá no final deste parágrafo, os entes abstractos, como os puramente matemáticos, não podem pertencer a nenhum género a não ser que sejam incluídos no género da quantidade de acordo com uma consideração lógica. Trata-se da natureza matemática, a qual parece ter como característica a sua dependência absoluta do intelecto. 

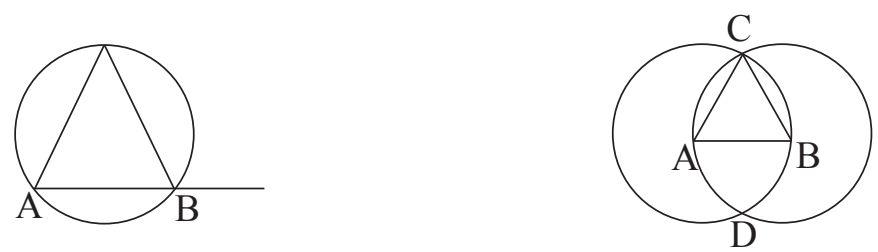

círculo máximo ${ }^{148}$ na última orbe celestial. Os dois pontos extremos de cada lado de um tal triângulo, a saber, A e B, não são os centros de dois círculos que se intersectam em dois pontos, a saber, $\mathrm{C}$ e $\mathrm{D}$, como se descreve na construção de um triângulo equilátero sobre uma linha recta, a primeira das conclusões da geometria $^{149}$. Com efeito, o círculo é anterior às linhas rectas de acordo com a existência natural, como é evidente segundo o Filósofo ${ }^{150}$; mas as demonstrações absolutas destas são anteriores às demonstrações dos círculos, como é evidente no edifício da arte da geometria. Pelo que se vê manifestamente que este ente, ou seja, o ente puramente matemático, tem nas suas partes esta ordem que adquire de acordo com aquele modo de ser no qual é constituído pelo intelecto. E visto que estes entes abstraem de toda a natureza e dos princípios naturais, não pertencem a nenhum género, propriamente falando, a menos que sejam incluidos num género de acordo com uma consideração lógica, e ao género que é a quantidade, o qual também não é uno de acordo com uma consideração metafísica ${ }^{151}$.

(52) Logo, estes entes que no modo referido tomam a sua entidade a partir de uma operação do intelecto, porque são quidificados de tal modo que são em si mesmos algo fora do intelecto, pelo que em si mesmos e originalmente são um objecto do intelecto, embora importando uma coisa natural, o que são as coisas de intenção primeira classificáveis num género - o que faz com que nenhum desses entes tendo em si completamente a natureza do seu género pode ser um não-ente ou convir ou ser atribuido ao não-ente, como é evidente quando se discutem os entes particulares, e nada há da sua noção nem nada pertence à sua noção definitiva que possa convir ao não-ente -, por causa disto, digo, são coisas de intenção primeira, pois que por causa disto aqueles entes referidos são em si mesmos e originalmente intencionados pela natureza e considerados pelo intelecto ${ }^{152}$.

148 O círculo máximo de uma esfera é o círculo que resulta da intersecção da esfera com um plano que lhe passa pelo centro, ou seja, que a intersecta.

149 Cf. Euclides, Elem. I, 1; ed. Heiberg-Stamatis, 7-8.

150 Aristóteles, De cael. I, 2, 269a19-20; ibid., II, 4, 286b17-8.

151 Secundum realem considerationem.

152 Parafraseando: é certo que estes entes constituídos deste modo por uma operação do intelecto importam uma coisa natural, um ente de intenção primeira classificável por si mesmo num género, mas eles existem em si mesmos fora do intelecto graças ao modo como este os quidifica, pelo que são também eles coisas de intenção primeira: tal como os entes naturais, em si mesmos e originalmente intencionados pela natureza e considerados pelo intelecto, eles são em si mesmos e originalmente um objecto do intelecto. Ou melhor: graças a eles os entes naturais são em si mesmos e originalmente considerados 
(53) Aqueles entes, porém, que chamamos coisas de intenção segunda não são assim ${ }^{153}$. Estes não tomam a sua entidade de modo tal que em si mesmos e originalmente sejam alguma coisa fora do intelecto, pelo que em si mesmos e originalmente sejam considerados pelo intelecto, sendo antes certas formas da parte do intelecto pelas quais as coisas se tornam racionais ${ }^{154}$. E assim, como que por acidente, o intelecto considera-as na medida em que por meio delas ele pensa acerca das coisas que ele considera em si mesmas. Segue-se que o intelecto reflecte sobre elas produzindo nelas a quididade e a entidade de acordo com a noção própria de cada uma delas, e isto é por acidente na medida em que são coisas de intenção segunda: por causa disto, de certo modo tomam o modo $<$ de ser> das coisas de intenção primeira, mas não se tornam por causa disto simplesmente coisas de intenção primeira, visto que esta entidade ou quididade não é produzida nelas por uma operação do intelecto a não ser em termos do seu modo essencial e no mesmo modo pressuposto neles pelo qual, como se disse, são coisas de intenção segunda. Estas são, por exemplo, o sujeito e o predicado, os termos maior ou menor ${ }^{155}$, a noção de um substantivo ou de um verbo, o género, a espécie, e outras coisas semelhantes ${ }^{156}$.

(54) Estes, porque são coisas de intenção segunda, podem ser considerados não só com respeito a entes, mas também com respeito a não-entes ${ }^{157}$. Com efeito, tanto não-entes como entes podem ocorrer numa combinação verbal e numa predicação afirmativa ou negativa, e se por acaso <alguns $>$ pertencem ao número daqueles que parecem somente convir às coisas existentes ${ }^{158}$, como o género e a espécie e intenções semelhantes, pode contudo ${ }^{159}$ pertencer à sua noção definitiva aquilo que convém tanto ao ente como ao não-ente, como aquilo que é o ser predicado, que pertence à sua definição: "o género", com efeito, "é aquilo que é predicado de muitas coisas diferentes", etc. ${ }^{160}$ Pelo que estes entes se chamam propriamente coisas de razão, ao contrário daqueles entes que são de intenção primeira, os quais importam uma coisa natural e dos quais o intelecto

pelo intelecto.

153 Teodorico vai agora explicar porque é que estes entes criados por uma operação do intelecto não são coisas de intenção segunda, como se crê.

$154 \mathrm{Ou}$ seja, pelas quais as coisas podem ser consideradas pela razão. Eis pois o que distingue as coisas de intenção primeira e as de intenção segunda: aquelas são por si mesmas e originalmente objecto do conhecimento; estas, pelo contrário, servem apenas para pensar outras coisas.

155 Cf. Aristóteles, De interp. 5-17a20; Boécio, In librum Aristotelis de interpretatione libri duo I, col. B-C.

156 Eis pois as coisas de intenção segunda: categorias e estruturas gramaticais e/ou lógicas, como a distinção sujeito - predicado e os universais.

157 Ao contrário das coisas de intenção primeira, que só podem ser atribuídas e convir ao ente (cf. 5, 52).

$158 \mathrm{Ou}$ seja, às coisas que de facto são, aos entes.

159 Lendo "similes intentiones, nihilominus" em vez de "similes intentiones. Nihilominus".

160 Boécio, L. de divis., PL 64/880 A. 
se ocupa do mesmo modo que das coisas naturais. Estes entes, propriamente falando, não se encontram no intelecto como formas da razão, mas são antes a partir do intelecto e existem fora dele, pois que são naquele modo no qual são determinados a existir pelo intelecto.

(55) É pois de certo modo evidente a diferença entre as coisas de intenção primeira e as de intenção segunda, embora sejam ambas constituídas por uma operação do intelecto. E por isto a resposta à objecção acima ${ }^{161}$ com respeito às coisas de intenção primeira e às de intenção segunda é evidente.

(56) Quanto à objecção que o intelecto é uma faculdade passiva e que por isso não parece ter o carácter de causa com relação a alguns entes ${ }^{162}$, deve-se em primeiro lugar responder que esta dúvida é comum às coisas de intenção primeira e às de intenção segunda; e porém é questão assente que as coisas de intenção segunda são a partir de um acto da razão ${ }^{163}$. Em segundo lugar, esta objeç̧ão não é válida pelo facto que o intelecto possivel não é uma faculdade passiva com respeito ao seu objecto, nomeadamente como algo é experienciado graças ao objecto, como se disse acima, mas tem o carácter e o modo de princípio passivo <somente> por comparação com o intelecto agente pelo qual ele é actualizado; e, assim actualizado, ele pode ser o princípio de uma operação inteligível pela qual a partir dos seus próprios princípios ${ }^{164}$ os entes podem ser quidificados no modo referido.

(57) Quanto àquilo que se introduz em terceiro lugar ${ }^{165}$, a saber, que nada é acrescentado pelo intelecto numa coisa exterior ${ }^{166}$, deve-se dizer, como é óbvio a partir do que se disse anteriormente ${ }^{167}$, que uma e a mesma coisa pode por vezes ser integralmente produzida a partir de causas de tipo diferente, de acordo com o que lhe são determinados princípios de uma outra noção por causas diferentes; e de acordo com isto não é uma coisa de uma noção única em relação às suas diferentes causas. Pelo que embora o intelecto não constitua a própria coisa nem produza nada numa coisa fora do intelecto segundo esta noção graças à qual ela é um ente natural $<\mathrm{e}>$ de acordo com a qual ela depende de princípios naturais, ele porém constitui essa mesma coisa de acordo com a noção pela qual ela é uma coisa especifica e tem uma existência quiditativa a partir dos princípios próprios

161 Trata-se da segunda das quatro objecções formuladas em 5, 5-8; esta segunda objecção é formulada em 5,6 .

162 Trata-se agora da primeira das objecções, formulada em 5, 5.

$163 \mathrm{Ou}$ seja, é questão assente que o intelecto tem o carácter de causa em relação às coisas de intenção segunda, pelo que nada obsta a que o possa ter também em relação às coisas de intenção primeira.

164 Do intelecto.

165 A terceira objecção, formulada em 5, 7.

166 Uma coisa existente fora do intelecto, res extra <intellectum $>$, ou seja, uma coisa natural.

167 Nomeadamente em 5, 37. 
do seu género ${ }^{168}$, como o homem a partir de animal e de racional, que é de facto um ente natural fora do intelecto ${ }^{169}$. Do mesmo modo, uma determinação relativa é constituída a partir dos princípios próprios que lhe são determinados pela razão, embora essa relação também pertença ao ente natural em virtude da noção do seu fundamento que importa no seu conceito com respeito a uma substância.

(58) Quanto ao que se introduziu em último lugar ${ }^{170}$, a saber, que por um acto da imaginação nada se produz com respeito a uma coisa, $<\mathrm{e}>\operatorname{logo}$, por um acto do intelecto também não, deve-se dizer que o acto da imaginação e o acto do intelecto com respeito a uma coisa existente fora do intelecto são simultaneamente semelhantes e diferentes. São semelhantes na medida em que assim como o intelecto compõe, também a imaginação $<_{o}$ faz $>$; pelo que tal como pelo acto composto ${ }^{171}$ da imaginação nada se produz com respeito a uma coisa - não é por eu imaginar um homem como tendo cornos que ele os tem de facto-, assim somente pelo acto composto do intelecto nada se acrescenta a uma coisa existindo fora do intelecto. Há porém uma diferença entre a imaginação e o intelecto quanto ao acto informativo que é a apreensão das intenções simples, ou seja, de entes não-compostos. Com efeito, disse-se acima ${ }^{172}$ que o intelecto apreende as coisas segundo a sua quididade, produzindo nelas a existência quiditativa a partir dos próprios princípios que são as partes da forma que a definição significa; e assim a coisa conhecida ${ }^{173}$ adquire a noção < própria> de objecto por uma operação do intelecto. A imaginação, porém, tal como a sensação, pressupõe no objecto tanto a espécie do seu objecto como a noção própria pela qual ela o possa apreender. Pelo que estas têm o carácter de princípio passivo com respeito ao seu objecto, enquanto o intelecto tem o carácter de princípio causal, como se disse acima, e não é preciso determo-nos mais nesta questão.

(59) É pois evidente de acordo com o que se disse que há certos entes que são pura e simplesmente coisas de razão na medida em que são a partir da razão, e são ao mesmo tempo formas da parte da razão <que se empregam> no conhecimento ${ }^{174}$ das coisas; e estas são simplesmente coisas de intenção segunda. Há ainda certos entes que são pura e simplesmente coisas naturais na medida em que segundo aquilo que são, são de acordo com a natureza e a partir de um

$168 \mathrm{Ou}$ seja, embora ela não deva ao intelecto o facto de ser uma coisa natural, uma coisa natural deve contudo a uma operação do intelecto o ser uma coisa específica e ter uma existência quiditativa a partir dos princípios do género a que pertence; por exemplo, um homem é com efeito um ente natural fora do intelecto, mas que ele é um animal racional - a sua especificidade ou existência quiditativa -, tal deve-o ao intelecto na medida em que o género, o qual não existe fora do intelecto, é ele próprio uma produção do intelecto. 169 É uma coisa que tem noções diferentes de acordo com as diferentes causas que contribuem simultaneamente para a sua criação.

170 A quarta e última objecção, formulada em 5, 8 .

171 Por oposição a acto simples; ainda: acto que implica uma composição.

172 Nomeadamente em 5, 26.

173 Ou pensada, res intellecta.

174 Ou pensamento; consideratio, no original. 
acto natural, como aqueles que são em si mesmos princípios de um movimento natural, como a substância, a qualidade, etc. Outros são como que num modo intermédio: quanto àquilo que se significa formal e principalmente pelo termo são a partir de uma operação do intelecto, mas em termos de uma qualquer natureza que eles importam no seu conceito, quer esta natureza seja uma substância, quer algo concreto de uma substância; e por isso estes são coisas de intenção primeira pela razão referida. Os exemplos são evidentes a partir do que se disse.

(60) A partir do que se disse, a razão da diferença que se considera nas diferentes perspectivas do metafísico, do filósofo natural e do matemático é evidente.

(61) Pois que o metafísico considera o ente enquanto ente, uma consideração do ente por essência em termos da sua quididade, excluidas de uma coisa as suas causas quer eficientes quer finais, segue-se que ele só define propriamente pela causa formal, uma definição que é o meio da demonstração exprimindo a razão de um qualquer modo ou propriedade que não importa nenhuma coisa natural com respeito a uma substância ou de modo geral à essência de uma coisa. A própria coisa pode, pela sua essência, ser a causa de um tal modo ou propriedade em termos da sua quididade, sendo excluidas todas as causas, tanto eficientes quanto finais.

(62) O mesmo não se passa no caso das coisas naturais ${ }^{175}$, no qual $<a$ existência de> uma qualquer coisa natural, que é necessário que exista num sujeito graças a um agente, se mostra com respeito a uma substância: mas o agente não produz esta coisa numa substância senão com um fim em vista. Logo, no caso das coisas naturais, para que a definição seja completa, é necessário que a causa eficiente e final concorde com a forma de uma coisa. E visto que o agente que produz uma determinada natureza num determinado sujeito com um determinado fim em vista não age senão a partir de um sujeito determinado ou matéria, a matéria também pertence à definição natural. Falo da matéria a partir da qual se dá a geração quanto à definição das substâncias naturais, como o mênstruo no animal, como o Filósofo indica com um exemplo no livro VIII da Metafisica ${ }^{176}$. A matéria que é a outra parte do composto não pertence à definição de uma substância natural nem na perspectiva do filósofo natural nem na do matemático, a não ser na medida em que importa no conceito uma forma que significa de modo concreto. Porém, na definição da forma substancial - seja qual for essa definição, uma coisa não é propriamente definível por si mesma - encontra-se a matéria; não contudo a matéria que com essa forma é a outra parte do composto, mas aquela que é posterior ao todo, do tipo que são as partes do todo que têm o carácter e o modo da matéria, como se diz no livro VII da Metafísica177, como são a carne e o osso, ou os órgãos, que são partes dos seres animados que pertencem à definição da alma. A razão disto é que $a$ matéria que é a outra parte do composto, tal como ela não quidifica uma coisa

\footnotetext{
175 Teodorico aborda agora a perspectiva do filósofo natural.

176 Aristóteles, Met. VIII, 4, 1044a34-5.

177 Ibid., VII, 10, 1035b9-12; 20-2.
} 
no sentido próprio, também não lhe dá a noção ${ }^{178}$, excepto talvez quando se fala de quididade em termos de consideração lógica, como o faz o Filósofo no livro VII da Metafísica ${ }^{179}$. Com efeito, só aquilo que é um acto dá a noção ${ }^{180}$ a uma coisa e de acordo com ele uma coisa é formalmente uma coisa específica: o sinal disto é que o Filósofo, praticamente em todo o lado ${ }^{181}$, ao falar da forma chama-a aquilo pelo qual uma coisa é uma coisa específica ${ }^{182}$. Mas se a definição é de uma qualquer forma acidental ou de uma paixão natural, a esta definição pertence a matéria ou o sujeito de uma tal forma pelo facto que não só por um agente natural com respeito a um fim natural, mas também de acordo com a natureza e o acto do sujeito esta forma tem inerência ${ }^{183}$.

(63) Mas o matemático, porque abstrai em relação ao movimento e à matéria, segue-se que não toma em consideração nas suas definições a matéria, a causa eficiente ou o fim. Ele só considera os entes que inerem em termos da forma, tanto definindo como demonstrando somente pela causa formal, como se diz no princípio do livro I de Dos Livros da Física ${ }^{184}$. Se porém nestes a matéria por vezes aparece nestas definições, tal acontece acidentalmente, como se tratará noutro lugar ${ }^{185}$.

(64) Mas de acordo com isto não parece haver nenhuma diferença entre o metafísico e o matemático. Com efeito, ambos consideram os entes que inerem num sujeito próprio essencialmente.

(65) Mas deve-se dizer que a diferença entre o metafísico e o matemático se encontra nos dois, isto é, no sujeito e no modo $<$ de ser $>$ do sujeito.

(66) O metafísico debruça-se sobre o ente enquanto ente e os entes que pertencem a um ente essencialmente, quer em termos de partes do ente, quer em termos de propriedades do ente. O matemático, por seu lado, ocupa-se do ente de um género determinado, o qual embora seja uma parte de um ente de modo simples, tal como o matemático o considera não inclui a noção geral do ente como uma parte de si, mas depende essencialmente dos seus próprios princípios, como os sujeitos das outras ciências com respeito à metafísica, e por isso são ciências diferentes da metafísica.

(67) A metafísica e a matemática diferem ainda quanto ao modo $<$ de ser $>$ do sujeito. O metafísico considera os entes que inerem em termos da quididade e da forma que se encontra na natureza e que tem um modo <de ser> natural. Por seu lado, o matemático ocupa-se dos entes que inerem em termos da forma abstraindo de toda a natureza e dos princípios naturais de acordo com a determinação do intelecto que produz neles este modo de ser. O metafísico nunca

\footnotetext{
178 Notificat.

179 Ibid., 4, 1030a23-7.

180 Notificat.

181 Met., VII, 7, 1032b1-2; ibid., 10, 1035b32; ibid., 17, 1041a26-8; ibid., VIII, 3, 1043b1-2; ibid., 4, 1044a36; ibid., V, 2, 1013a26-8; Phys. II, 2, 194a20-1; ibid., 3, 194b26-7.

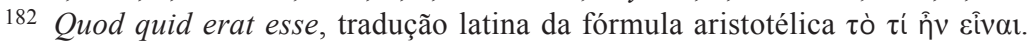

183 Ou seja, inere num sujeito.

184 Cf. Averróis, In Aristotelis Phys. I, comm. 1; Venetiis, 1562, 6rB-C.

185 Não se identificou a referência.
} 
definiria um triângulo como sendo uma figura plana tendo um ângulo extrínseco, etc.: esta definição não convém ao triângulo enquanto é um ente natural, como se disse acima. Entendo aqui "natureza" num sentido geral, de acordo com o qual também os entes separados se chamam e são entes naturais ${ }^{186}$.

(68) Destas considerações pode-se, à maneira de um corolário, concluir se conhecemos entes separados ou individuais. Mas será mais oportuno tratar deste assunto no tratado Acerca do Intelecto e do Inteligível ${ }^{187}$, que deverá seguir-se a este na ordem devida, se Deus quiser.

(69) Estas considerações num modo investigativo acerca da origem das coisas categoriais são por agora suficientes.

186 Ou seja, Teodorico volta a alargar o conceito de natureza de modo a incluir, além dos entes corpóreos, os entes ditos separados ou puramente abstractos (separata ab sensibilibus), como já o havia feito no Capítulo 1.

187 Teodorico Teutónico, De intell. III, 16ss. 